I N T ER N ATIONAL MONETARY FUND

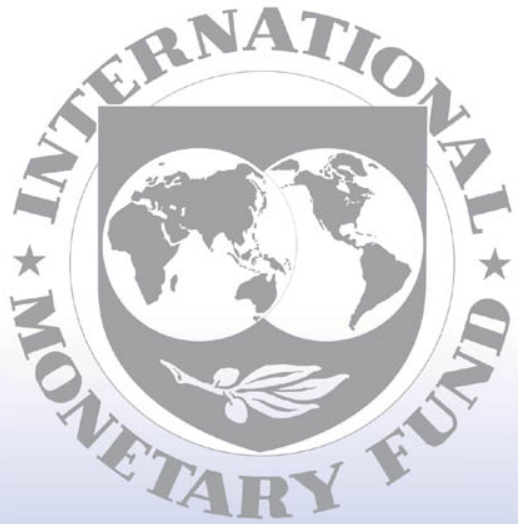

Staff

Country

Reports 


\title{
Botswana: 2009 Article IV Consultation-Staff Report; Public Information Notice on the Executive Board Discussion; and Statement by the Executive Director for Botswana
}

Under Article IV of the IMF's Articles of Agreement, the IMF holds bilateral discussions with members, usually every year. In the context of the 2009 Article IV consultation with Botswana, the following documents have been released and are included in this package:

- $\quad$ The staff report for the 2009 Article IV consultation, prepared by a staff team of the IMF, following discussions that ended on May 15, 2009, with the officials of Botswana on economic developments and policies. Based on information available at the time of these discussions, the staff report was completed on July 2, 2009. The views expressed in the staff report are those of the staff team and do not necessarily reflect the views of the Executive Board of the IMF.

- $\quad$ A Public Information Notice (PIN) summarizing the views of the Executive Board as expressed during its July 20, 2009 discussion of the staff report that concluded the Article IV consultation.

- A statement by the Executive Director for Botswana.

The policy of publication of staff reports and other documents allows for the deletion of market-sensitive information.

\author{
Copies of this report are available to the public from \\ International Monetary Fund • Publication Services \\ $70019^{\text {th }}$ Street, N.W. • Washington, D.C. 20431 \\ Telephone: (202) 623-7430 • Telefax: (202) 623-7201 \\ E-mail: publications@imf.org Internet: http://www.imf.org
}

\section{International Monetary Fund Washington, D.C.}




\section{INTERNATIONAL MONETARY FUND}

\section{BOTSWANA}

\section{Staff Report for the 2009 Article IV Consultation}

Prepared by the Staff Representatives for the 2009 Consultation with Botswana Approved by Saul Lizondo and Dhaneshwar Ghura

July 2, 2009

- Dates: May 6-15, 2009. The mission met with Minister of Finance and Development Planning Gaolathe, Bank of Botswana Governor Mohohlo, other senior government officials, the donor community, and representatives of the private sector and civil society.

- $\quad$ Team: Mr. Thugge (head), Mr. Davoodi, Mr. Gaertner, Mr. Kpodar and Ms. Topak (all AFR). Ms. Mannathoko (OED) and a representative from the World Bank also attended some meetings.

- $\quad$ Botswana has accepted the obligations of Article VIII, Sections 2, 3, and 4 of the Articles of Agreement and maintains an exchange system free of restrictions on the making of payments and transfers for current international transactions. The exchange rate regime is a crawling peg against a basket of currencies.

- Botswana participates in the General Data Dissemination System; data provision is adequate for surveillance. 


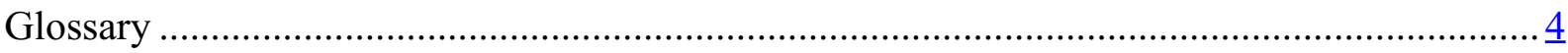

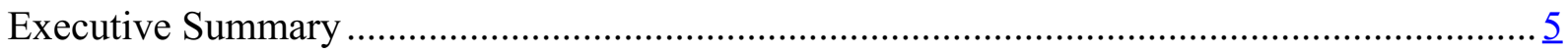

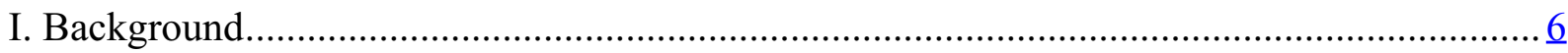

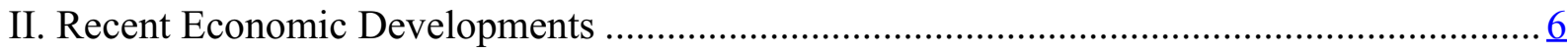

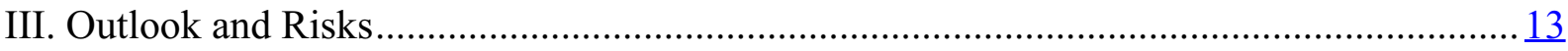

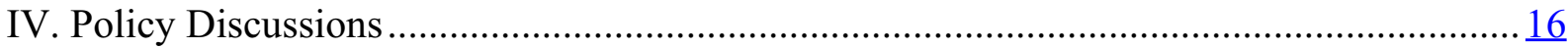

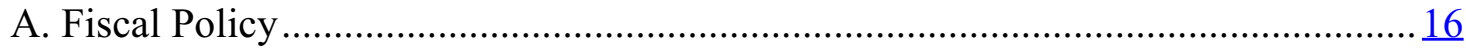

B. Monetary and Exchange Rate Policies............................................................ 19

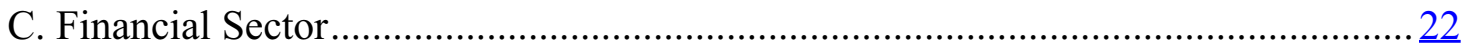

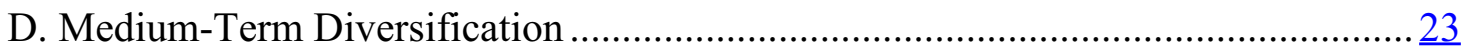

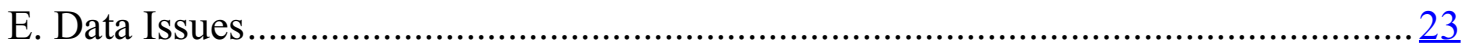

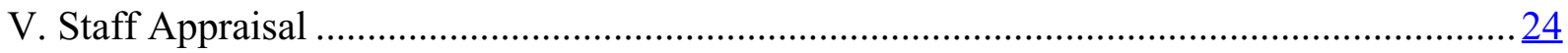

Text Tables

1. Comparative Social Indicators, 2007 .............................................................................. 8

2. Income Distribution, Poverty and Unemployment ................................................... $\underline{8}$

3. Medium-Term Economic and Financial Indicators, 2007-14 ....................................... 14

4. Medium-Term Fiscal Outlook and Sustainability Benchmarks ....................................18

Tables

1. Medium-Term Economic and Financial Indicators, 2007-14 ........................................ 26

2. Sectoral GDP and Savings Investment Balances, 2007-14 …....................................... 27

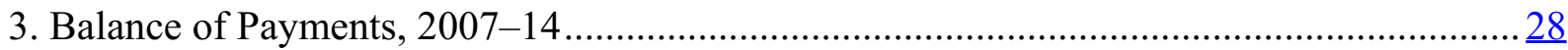

4a. Central Government Operations, 2007/08-13/14 …..................................................... 29

4b. Central Government Operations, 2007/08-11/12 .................................................... $\underline{30}$

4c. Central Government Operations, 2007/08-13/14 ....................................................... $\underline{31}$

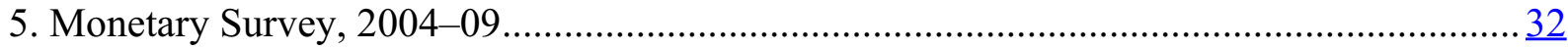

6. Banking System Prudential Indicators, 2004-09 ........................................................ $\underline{33}$

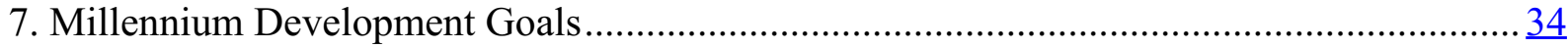

8. Competitiveness Rankings.................................................................................... $\underline{35}$

Figures

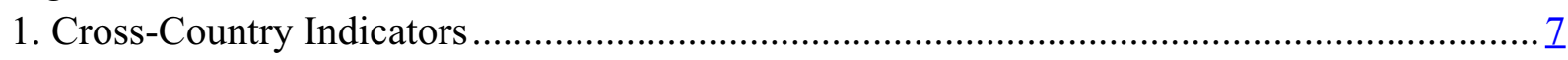

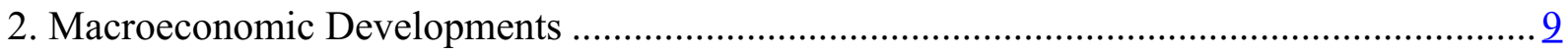

3. Macroeconomic Developments ......................................................................... 10

4. Financial Sector Developments ................................................................................. 13 
5. Selective Competitiveness Indicators

\section{Boxes}

1. Recent Developments in the Diamond Sector ...................................................................11

2. Economic Impact of Lower Diamond Output and Absence of the Mmamabula Project..... 15

3. Implementation of Previous Fund Policy Advice.......................................................... 16

4. Exchange Rate and Competitiveness Assessment ………….......................................... 20

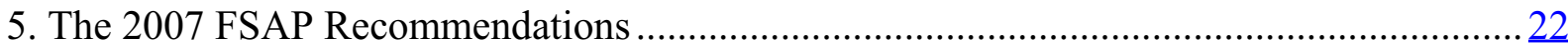

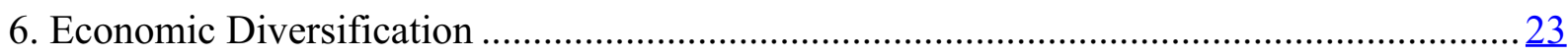




\section{GLOSSARY}

AfDB

ARV

BoB

BoBCs

EREER

GDDS

MTEF

NBFIRA

NDP10

NMPD

PIH

REER

SARB

SDDS

VAT

African Development Bank

Anti-Retroviral

Bank of Botswana

Bank of Botswana Certificates

Equilibrium real effective exchange rate

General Data Dissemination System

Medium-term expenditure framework

Nonbank Financial Institutions Regulatory Authority

National Development Plan 10

Nonmining primary deficit

Permanent income hypothesis

Real effective exchange rate

South African Reserve Bank

Special Data Dissemination Standard

Value-added tax 


\section{EXECUTIVE SUMMARY}

\section{Background and outlook}

- $\quad$ Sound macroeconomic management, underpinned by strong institutions and good governance, has sustained Botswana's strong macroeconomic performance in recent years. Real GDP growth averaged 4 percent over the past five years, with average fiscal and current account surpluses of 5 and 11 percent of GDP, respectively, over this period.

- However, the current global economic crisis has reduced demand for diamonds and contributed to a significant deterioration in the economic outlook. The economy is now projected to contract sharply in 2009, and large fiscal and external deficits are anticipated. Inflation has slowed considerably and is projected to fall to 7 percent by the end of 2009. In the medium-term, real GDP is expected to rebound as diamond output recovers, and two large electricity generation projects begin production.

\section{Policy issues and authorities' response}

- In light of rapid growth in spending in recent years, staff raised concerns about the quality of expenditure and the need to reduce it to a more sustainable level over the medium term. The authorities acknowledged there was some scope to improve spending efficiency, but emphasized the exceptional circumstances facing the country in 2009, and explained that development spending would decline as on-going infrastructure projects are completed.

- $\quad$ Staff recommended an alternative fiscal rule based on the nonmining primary deficit (NMPD) as a share of nonmining GDP rather than the current limit on overall expenditure relative to total GDP. This would provide a clearer indication of the underlying fiscal stance and medium-term fiscal sustainability. The authorities indicated that a revision to their fiscal rule to incorporate a link to non-mining GDP was being considered, but did not commit to an NMPD target.

- $\quad$ Staff concurred with the authorities' view that the weak outlook for growth and expected decline in inflation should allow further monetary policy easing.

- $\quad$ The financial sector has weathered the global economic downturn thus far, although non-performing loans have edged up. The authorities indicated that they are closely monitoring banks' loan portfolios and will be taking further steps to improve supervision of nonbank financial institutions.

- $\quad$ The sharp contraction in real GDP expected in 2009 underscores the need to accelerate structural reforms to increase productivity and economic diversification. The authorities' diversification strategy focuses on improving infrastructure in key sectors and investing in education and health to build up human capital and boost productivity. 


\section{BACKGROUND}

1. Sound macroeconomic management, supported by strong institutions and good governance, has underpinned strong economic growth in Botswana for the past four decades. Annual real GDP growth averaged nearly 10 percent per year from 1960 through 2008 , supported by increased mining production and more recently by stronger growth in the nonmining economy as the mining sector has matured (Figure 1). As a result, real per capita income increased from US\$250 in 1960 to US\$4,800 in 2008 (in constant 2000 US\$).

2. Prudent management of diamond revenues, together with high minerals' prices, resulted in large fiscal and external surpluses in recent years. International reserves rose to 21 months of imports of goods and services by end-2008, boosted by the accumulation of sizable fiscal savings.

3. Despite this impressive progress, considerable social challenges remain. HIV/AIDS is a serious problem, while poverty, unemployment, and income inequality are all high for a middle-income country (see Text Tables 1 and 2). In addition, the economy continues to rely heavily on diamond mining, which is expected to decline after 2020. Greater progress on economic diversification will be critical to sustain high growth and reduce poverty and inequality.

\section{RECENT ECONOMIC DEVELOPMENTS}

\section{After several years of robust growth, real GDP growth slowed to 2.9 percent} in 2008 due to a decline in mining output (Figure 2). Value added in the mining sector decreased by 3.7 percent in 2008 as demand for diamonds fell sharply in the fourth quarter. With demand for diamonds remaining weak in early 2009 and a significant amount of inventory accumulating, diamond mining was suspended from January through mid-April (Box 1).

5. The decline in diamond exports, together with a large increase in public infrastructure-related imports, reduced the current account surplus to 7 percent of GDP in 2008. This compared with an average surplus of 15.6 percent of GDP during 20052007. International reserves declined from US $\$ 10$ billion in mid-2008 to US $\$ 8.1$ billion in March 2009, equivalent to 16 months of imports of goods and services. 
Figure 1. Cross-Country Indicators
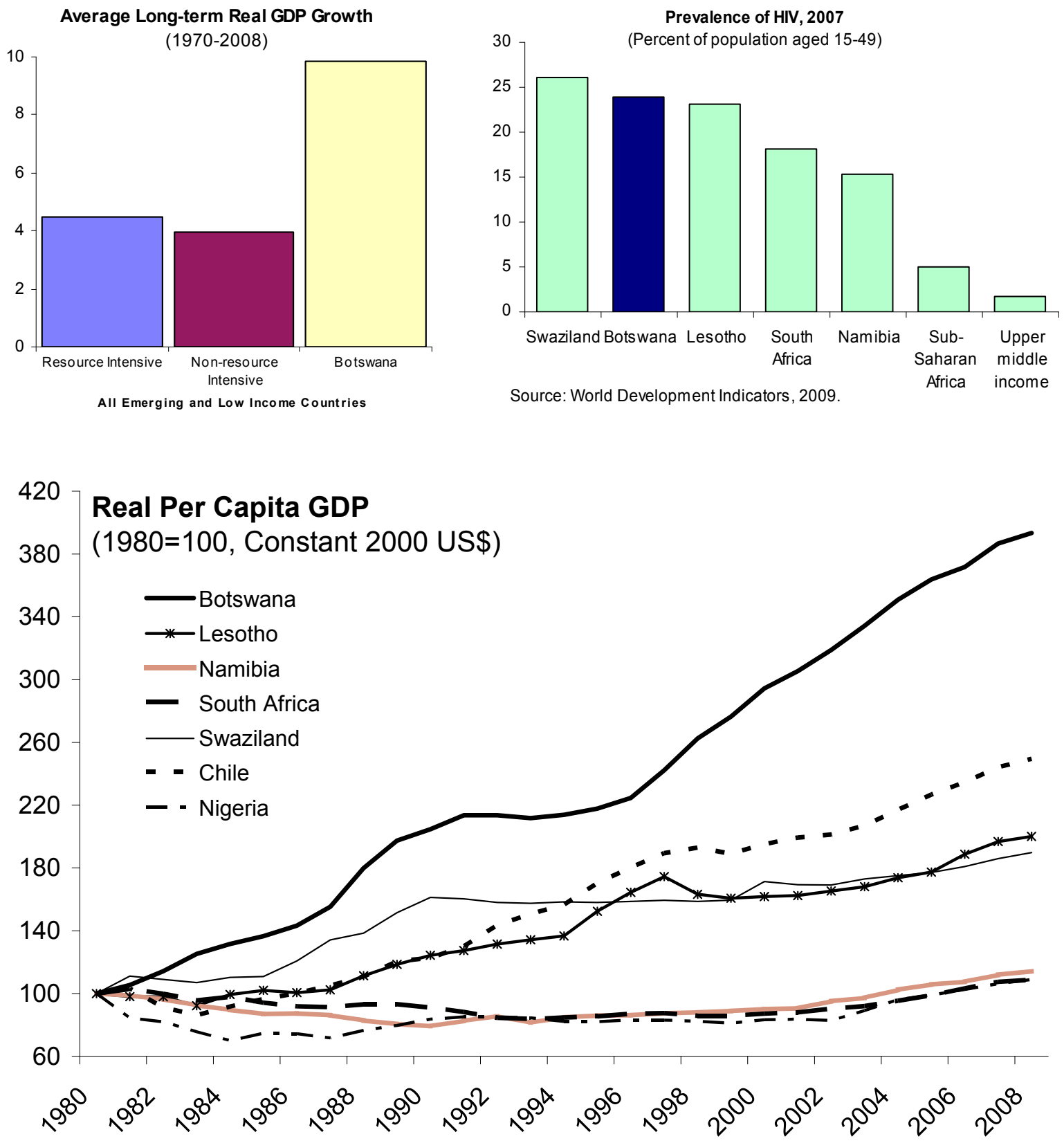

Source: World Development Indicators, 2009.

Sources: UN COMTRADE Database, Bank of Botswana, World Economic Outlook, and IMF staff calculations. 
Text Table 1. Comparative Social Indicators, 2007

\begin{tabular}{|c|c|c|c|c|c|c|}
\hline Country & $\begin{array}{l}\text { GNI per Capita, } \\
\text { (Atlas method, } \\
\text { US\$) }\end{array}$ & $\begin{array}{l}\text { Total Life } \\
\text { Expectancy } \\
\text { at Birth } \\
\text { (years) }\end{array}$ & $\begin{array}{c}\text { Infant Mortality } \\
\text { Rate (per } 1,000 \\
\text { live births) }\end{array}$ & $\begin{array}{c}\text { Prevalence of HIV } \\
\text { (percent of population } \\
\text { ages 15-49) }\end{array}$ & $\begin{array}{l}\text { Primary School } \\
\text { Completion Rate } \\
\text { (percent of relevant } \\
\text { age group) }{ }^{2}\end{array}$ & $\begin{array}{c}\text { Population } \\
\text { Growth } \\
\text { (percent) }\end{array}$ \\
\hline Botswana $^{1}$ & 6,120 & 50.6 & 40 & 17.6 & 94.6 & 1.2 \\
\hline Chile & 8,190 & 78.4 & 9 & 0.3 & .. & 1.0 \\
\hline Lesotho & 1,030 & 42.6 & 84 & 23.2 & 78.3 & 0.5 \\
\hline Malaysia & 6,420 & 74.3 & 11 & 0.5 & 98.3 & 1.7 \\
\hline Mexico & 9,400 & 74.9 & 35 & 0.3 & 103.6 & 1.0 \\
\hline Namibia & 3,450 & 52.8 & 68 & 15.3 & 77.1 & 1.6 \\
\hline Poland & 9,850 & 75.1 & 7 & 0.1 & 96.8 & -0.1 \\
\hline South Africa & 5,720 & 50.5 & 59 & 18.1 & 92.2 & 1.0 \\
\hline Swaziland & 2,560 & 39.6 & 91 & 26.1 & 58.6 & 0.7 \\
\hline Sub-Saharan Africa & 951 & 50.8 & 146 & 5.0 & 59.9 & 2.4 \\
\hline Upper middle income & 7,107 & 71.0 & 24 & 1.7 & 100.6 & 0.7 \\
\hline World & 7,995 & 68.8 & 68 & 0.8 & 86.3 & 1.2 \\
\hline
\end{tabular}

Source: World Development Indicators database, 2009.

${ }^{1}$ For Botswana, the data on HIV prevalance are from the National AIDS Coordinating Agency, BAIS III, 2008 and are for the entire population aged 18 months and above.

${ }^{2}$ Latest data available. A figure above 100 percent indicates that some students repeat their primary education.

Text Table 2. Income Distribution, Poverty, and Unemployment

\begin{tabular}{lccc}
\hline & & & \\
Country & & & \\
& Gini Index & & \\
& & Poverty $^{2}$ & Unemployment $^{3}$ \\
\hline Botswana & & \multicolumn{2}{c}{ (Percent) } \\
Chile & 61 & 22.3 & 17.6 \\
Lesotho & 52 & 0.5 & 8.9 \\
Malaysia & 53 & 33.0 & 27.3 \\
Mexico & 38 & 1.4 & 3.1 \\
Namibia & 48 & 1.0 & 3.4 \\
Poland & 74 & 36.5 & 21.9 \\
South Africa & 35 & 0.5 & 9.6 \\
Swaziland & 58 & 18.3 & 23.0 \\
Sub-saharan Africa & 51 & 45.8 & 22.5 \\
Upper middle income & $\ldots$ & $\ldots$ & $\ldots$ \\
World & $\ldots$ & $\ldots$ & 8.7 \\
\hline
\end{tabular}

Source: World Bank, World Development Indicators 2009.

Note: Most of the data refer to 2007; the latest data available has been used for others.

${ }^{1}$ A measure of distribution of income, where 0 represents perfect equality and 100 represents perfect inequality. For Botswana, the figure represents cash income only.

${ }^{2}$ Poverty at below $\$ 2 /$ day PPP basis.

${ }^{3}$ The figure for Botswana is from the 2005-2006 Labour Force Survey. 
Figure 2. Macroeconomic Developments

Real GDP is likely to contract in 2009 as mining output falls ...

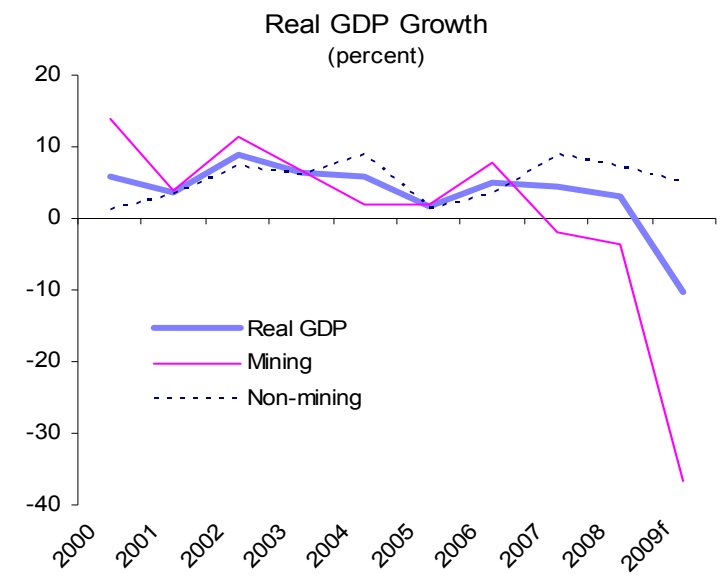

An increase in investment-related imports, together with falling mineral exports, ...

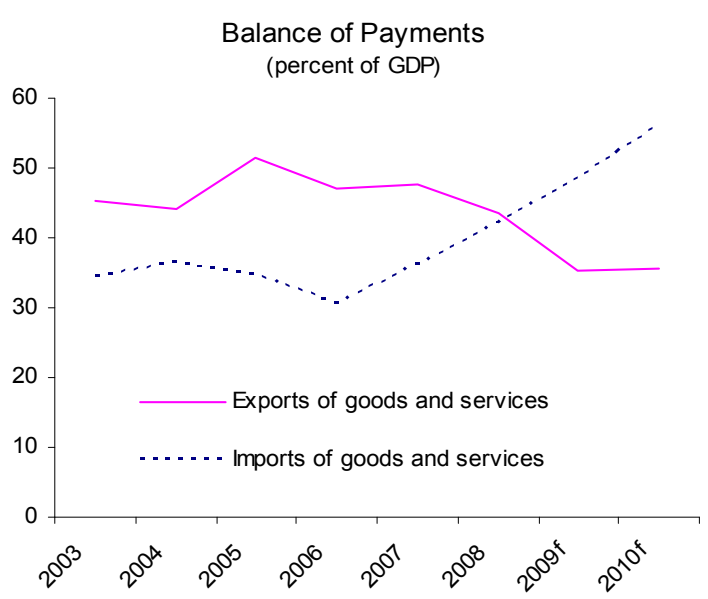

Reserve coverage is projected to decline in 2009, but should remain at a comfortable level.

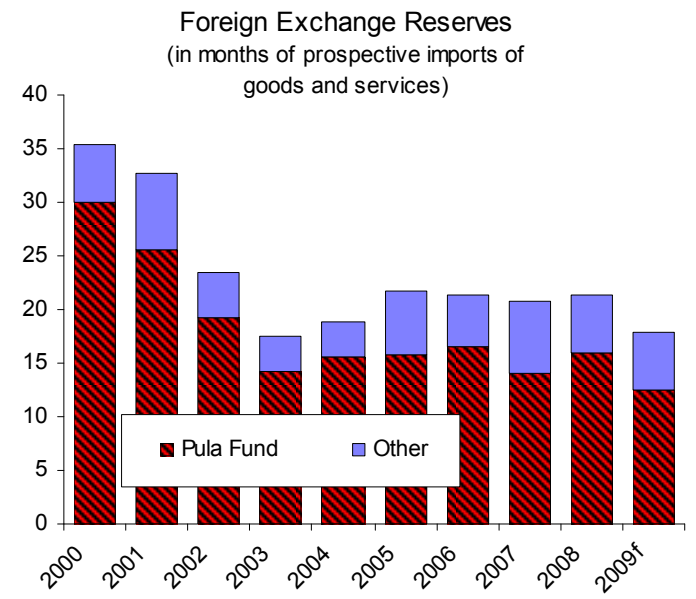

... but inflation has begun to moderate in line with food and energy prices.

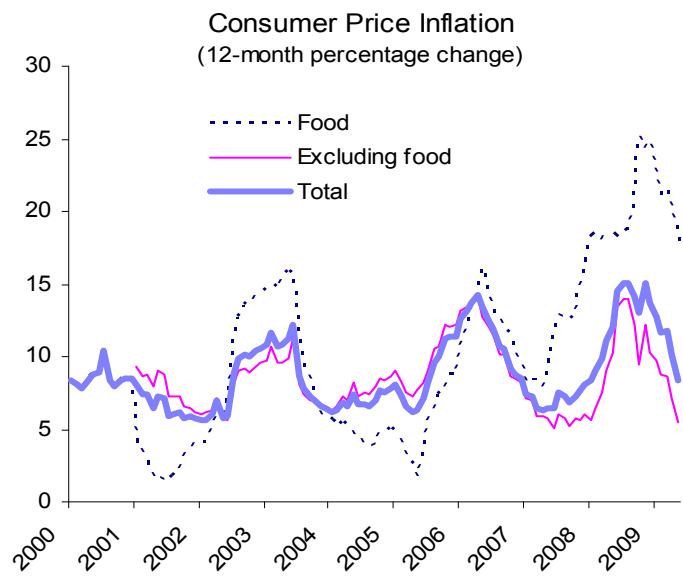

... is likely to result in large current account deficits in 2009-10.

Balance of Payments (percent of GDP)

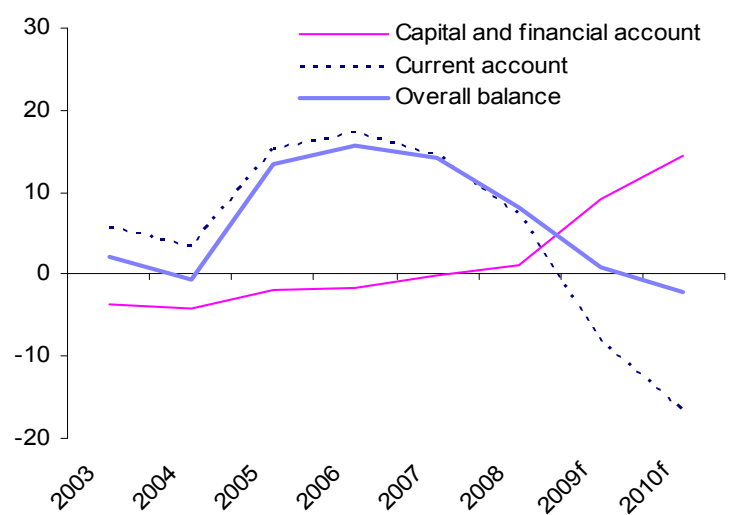

External debt remains relatively low, but it will increase considerably in 2009-10.

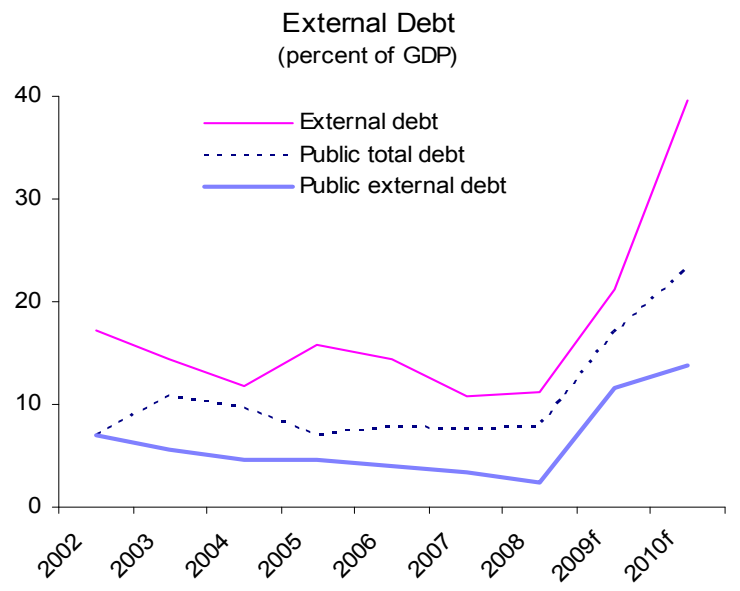




\section{Figure 3. Macroeconomic Developments}

The $B o B$ has lowered interest rates in line with slowing inflation.

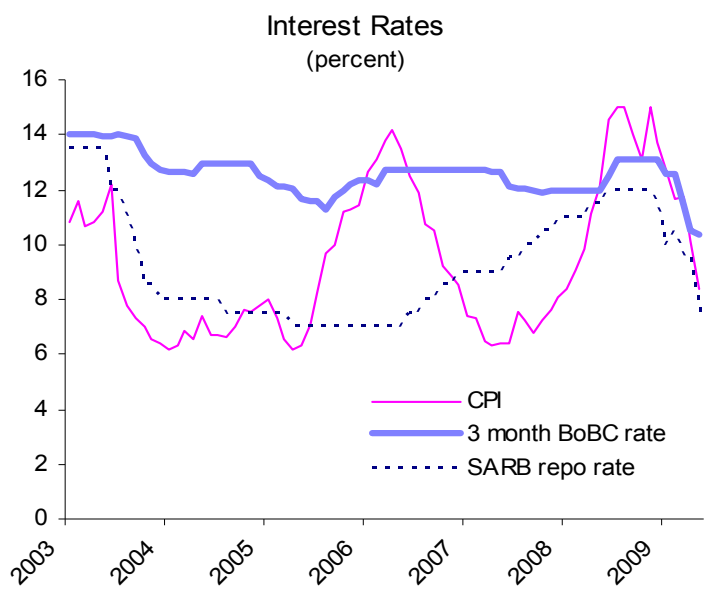

An increase in inflation differentials resulted in modest REER appreciation in 2008 and early 2009.

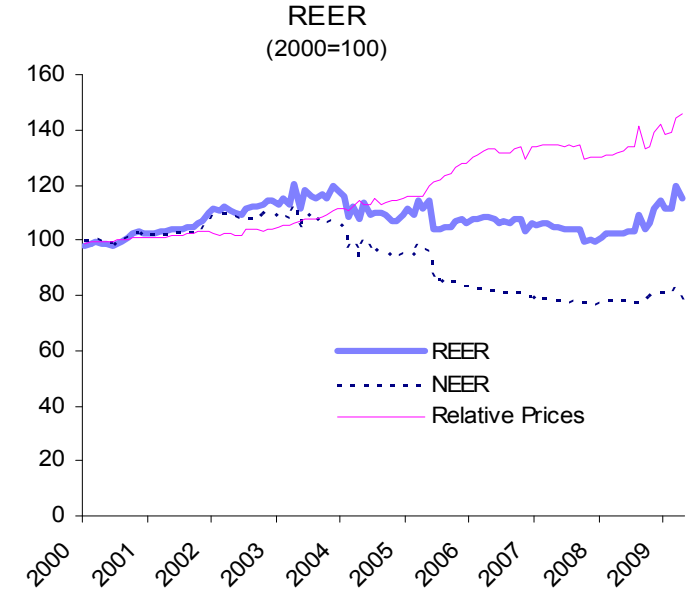

Mineral revenues are likely to decline further ...

Central Government Operations (percent of non-mineral GDP)

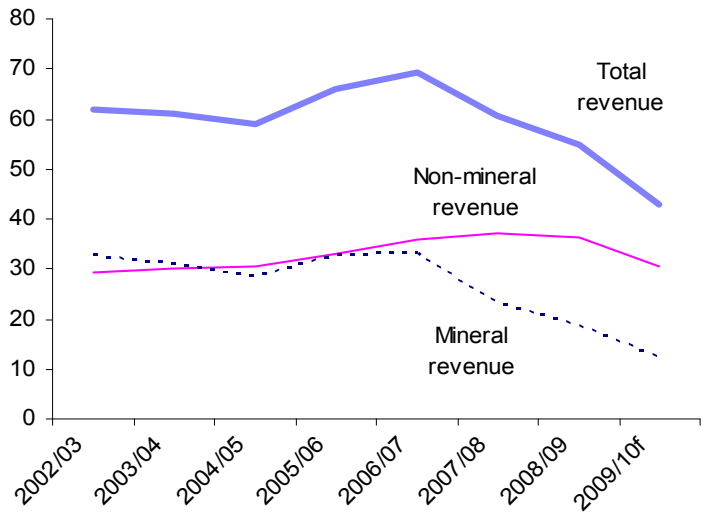

Credit growth has been strong over the past two years, but appears to be slowing.

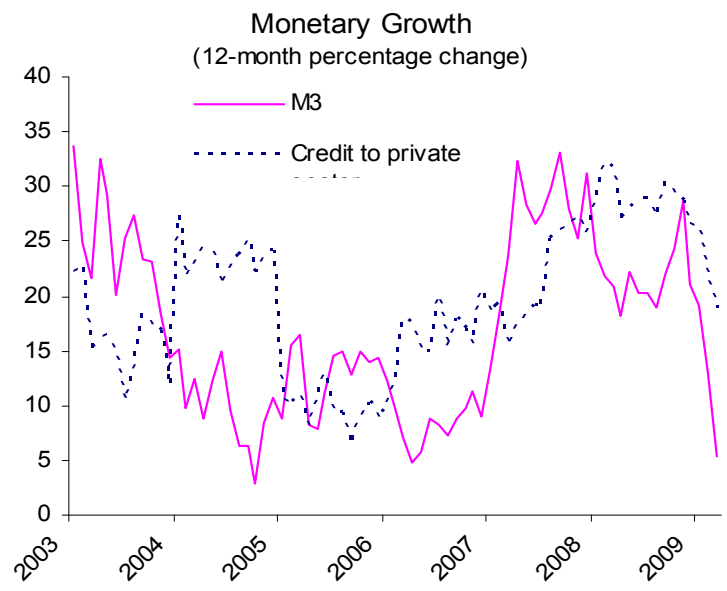

The nonmining primary deficit is projected to remain unchanged in 2009/10.

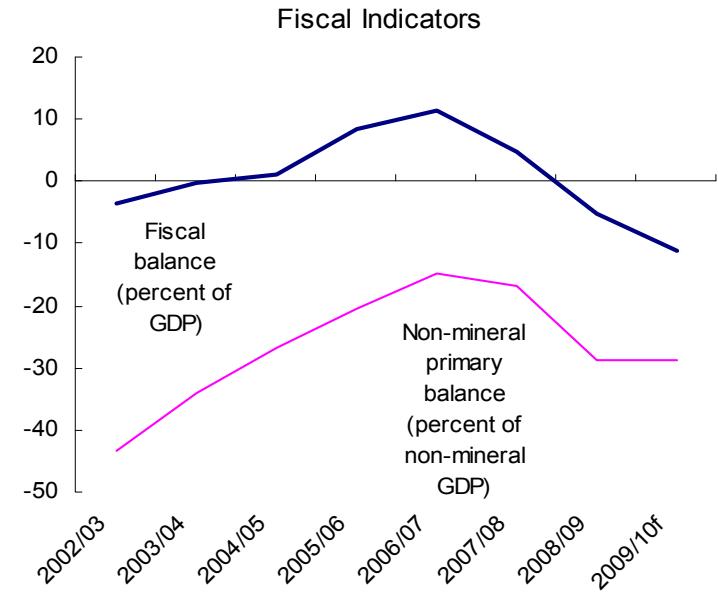

... but spending should moderate after the sizable increase last year.

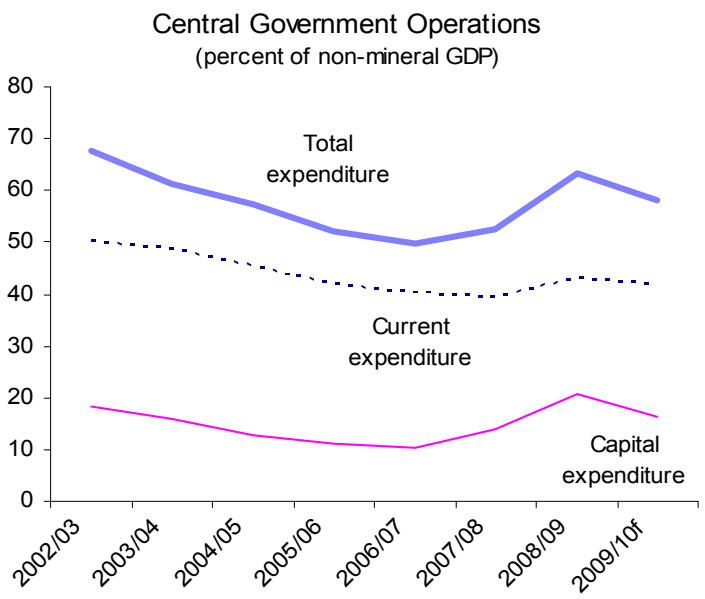




\section{Box 1. Recent Developments in the Diamond Sector}

Botswana is one of the world's leading diamond producers, with a market share of about 20 percent. Production is conducted almost exclusively by Debswana, a 50-50 joint venture of DeBeers and Botswana; Botswana also holds a 15 percent stake in DeBeers. Botswana's diamond production has increased steadily in recent years, and in 2008 contributed about 40 percent of fiscal revenues, 35 percent of GDP, and 62 percent of total exports. As a step toward development of a local downstream diamond industry, the Diamond Trading Company Botswana was launched in 2008 to sort and aggregate diamonds locally.

The global financial crisis caused a significant decline in demand for diamonds in the fourth quarter of 2008 and early 2009. As a result, Debswana suspended production in early 2009; in April the mines at Jwaneng, Orapa \#1 and Letlhakane resumed production, though at reduced capacity, while the mines at Damtshaa and Orapa \#2 will remain closed through December. Diamond prices also fell sharply in the fourth quarter of 2008. Total diamond production in 2009 is estimated to be 20 million carats, nearly 40 percent less than in 2008. Debswana expects output to return to full capacity by 2012 as the global economy strengthens, but there is considerable uncertainty about when a sustained recovery in demand will occur.
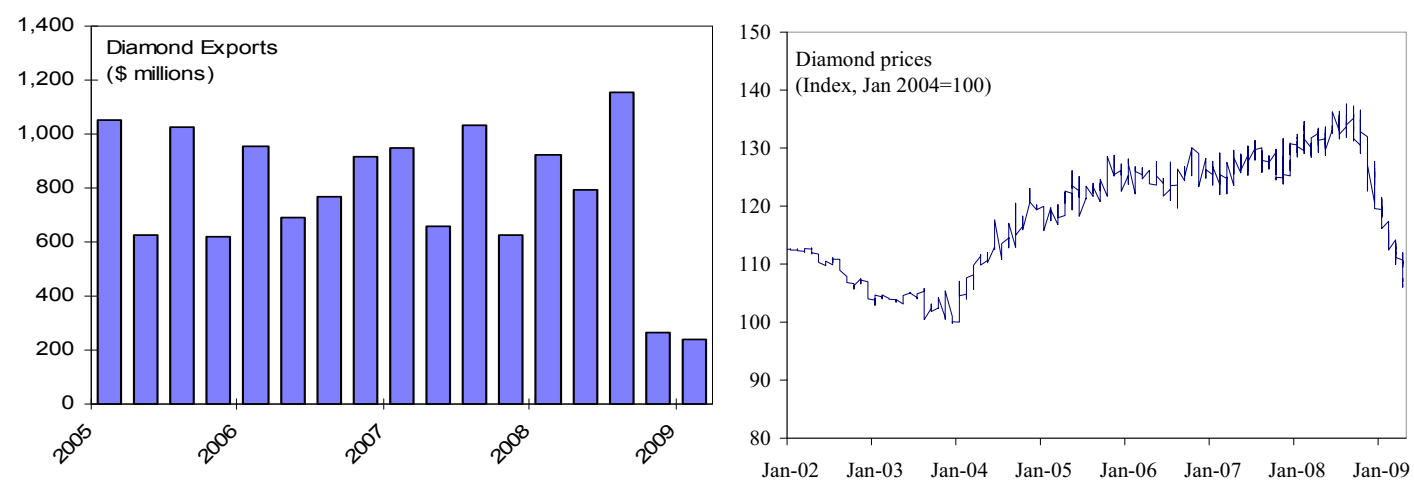

Sources: National authorities, and PolishedPrices.com.

\section{The nonmining primary deficit (NMPD) ${ }^{1}$ amounted to 28.6 percent of non-} mining GDP in 2008/09, well above the 16.8 percent NMPD in 2007/08 (Figure 3). The larger deficit mostly reflected a surge in spending to 63 percent of nonmining GDP from 52.5 percent in 2007/08. Current expenditure rose 12.5 percent in real terms, reflecting a further increase in the public sector wage bill, while development spending increased by 54 percent in real terms as the government accelerated the construction of airports, roads, dams, schools and the Morupule electricity generation project. Increased spending also

\footnotetext{
${ }^{1}$ The NMPD is calculated as the difference between nonmining revenue and expenditure (excluding interest receipts and interest payments).
} 
reflected a public works program to provide income support for vulnerable groups and measures to offset higher food prices.

7. The NMPD is projected to remain broadly unchanged in $2009 / 10$. The original 2009/10 budget had proposed a further real spending increase of 4 percent over the revised budget, which would have raised the NMPD to 34 percent of non-mining GDP. However, the government has announced plans to scale back recurrent spending by 7 percent and development spending by 5 percent, which staff projects would stabilize the NMPD at 28.3 percent of non-mining GDP. The overall deficit of 11.1 percent of GDP is expected to be fully financed by an AfDB budget support loan (US\$1.5 billion).

\section{Botswana continues to peg the pula to a basket of the rand and the SDR in an} effort to maintain a stable real effective exchange rate (REER). The rate of crawl is determined on the basis of the difference between domestic inflation and trading partner inflation. ${ }^{2}$ The real effective exchange rate has stabilized since the shift to the crawling peg regime in May 2005, although Botswanas̉ higher inflation vis-àvis its trading partners resulted in a modest appreciation in 2008 and early 2009.

\section{The twelve-month inflation rate fell to 8.4 percent in May 2009 from 15 percent} in mid-2008, mostly reflecting reduced pressure on fuel and food prices. Inflation is expected to decline further toward the upper end of the Bank of Botswana's (BoB) mediumterm (three-year) inflation objective of 3-6 percent. With inflationary pressures easing, the $\mathrm{BoB}$ has reduced its main interest rate by 250 basis points since December 2008 with a view to stimulating economic activity. The outstanding stock of Bank of Botswana Certificates (BoBCs), which are used for liquidity management purposes, has declined since mid-2008 due to increased issuance of government domestic debt and reduced foreign inflows. ${ }^{3}$

\section{Thus far, the financial sector has been relatively unscathed by the turmoil in} international financial markets. Conservative lending practices and limited international exposure appear to have insulated commercial banks, and they remain well-capitalized, liquid and profitable (Figure 4). Nonperforming loans are at very low levels despite a modest increase in late 2008 and early 2009, although a weaker economy and rising unemployment could lead to a further deterioration in asset quality. As elsewhere, the global financial crisis has adversely affected the value of assets held by domestic pension and insurance funds, but these funds remain financially sound and profitable.

\footnotetext{
2 The Bank of Botswana Annual Report of 2008 notes that "the annual rate of crawl is determined on the basis of the differential between Botswana's inflation objective and forecast inflation for trading partner countries."

${ }^{3}$ The government issued a total of P2 billion (equal to 2.2 percent of GDP) in September 2008 and March 2009 as part of its P5 billion Government Note Issue program to help develop the domestic capital market.
} 
Figure 4. Financial Sector Developments
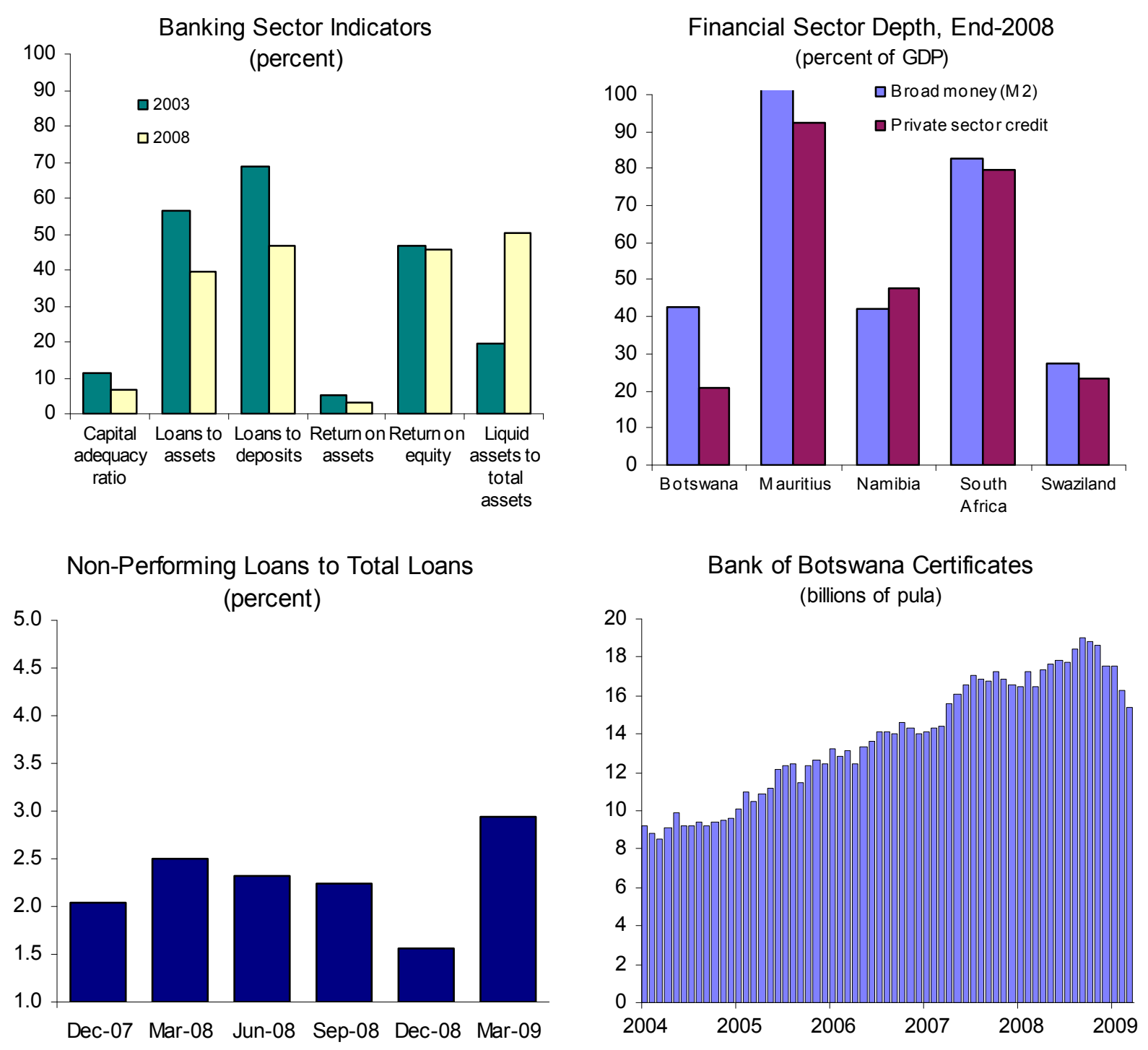

\section{OUTLOOK AND RISKS}

\section{Real GDP is projected to contract by $\mathbf{1 0}$ percent in $\mathbf{2 0 0 9}$ as diamond production} declines (see Text Table 3). Diamond output is expected to fall by 40 percent, reflecting the marked weakening in external demand since late 2008. The downturn in the diamond sector is also likely to contribute to slower growth in the nonmining sector, although large public expenditures for several ongoing infrastructure projects should help sustain nonmining growth of 5 percent in 2009. A modest rebound is projected for 2010, with a stronger recovery in 2011-12 as diamond output returns to full capacity. In addition, two large electricity generation projects (Morupule and Mmamabula) should boost growth after 2012. 
Text Table 3. Medium-Term Economic and Financial Indicators, 2007-2014

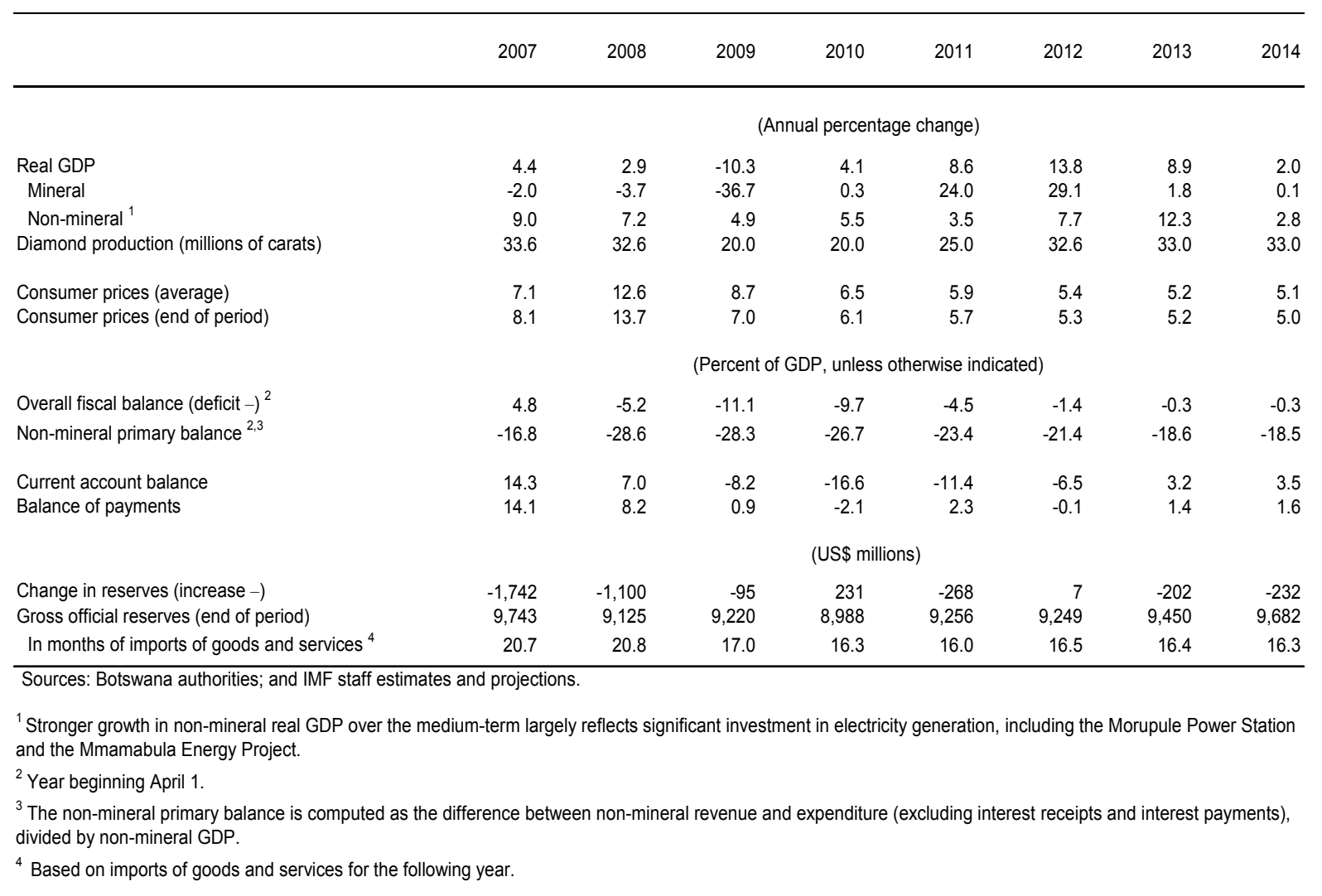

\section{The external position is projected to deteriorate in 2009-10, but should improve}

thereafter. Botswana's current account balance is expected to shift to a deficit of 8.2 percent of GDP in 2009, and widen further to 16.6 percent of GDP in 2010 because of the decline in diamond exports and an increase in imports related to the construction of the two power stations. However, by 2013 the current account is expected to shift to a surplus as these projects are completed and diamond production returns to full capacity. Gross international reserves are projected to remain at least 16 months of import cover throughout the projection period.

\section{Despite the rapid build-up of external debt in 2009, Botswana is at little risk of} debt distress (see Debt Sustainability Analysis in the Informational Annex). External debt is expected to reach nearly 50 percent of GDP by 2012 to finance construction of the two power stations, but would stay below 60 percent of GDP in the stress-test scenarios. Public debt would rise to 25 percent of GDP by 2010, before falling to 15 percent by 2014. If growth and the primary balance were to return to recent levels, however, Botswana would be able to repay its public debt by 2012 . 


\section{Box 2. Economic Impact of Lower Diamond Output and Absence of the Mmamabula Project}
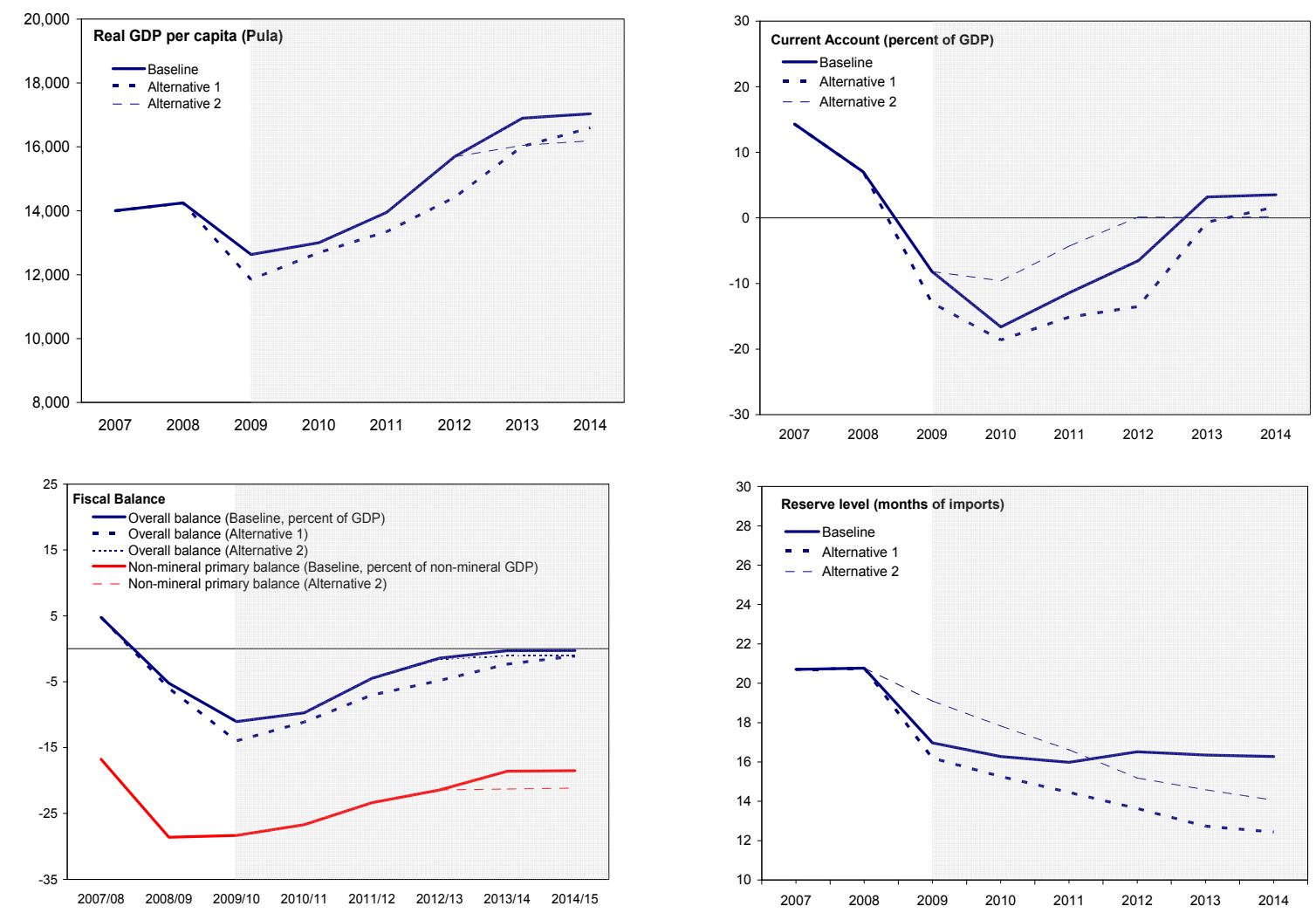

Source: Botswana authorities and IMF staff estimates and projections.

14. There are significant downside risks to the economic outlook over the next several years. Staff considered two alternative scenarios: (i) a larger reduction (54 percent) in diamond production in 2009 with a slower recovery in international demand; and (ii) that the Mmamabula project, does not move forward (Box 2). Both scenarios would have a significant impact on the fiscal and external positions. The authorities broadly shared staff's assessment of the outlook and noted there was a risk that a recovery of diamond production to pre-crisis levels could take several years.

\section{The fall in diamond production expected after 2020 clouds the longer-term}

outlook. Although there has been some progress toward diversification, the nonmining sector continues to be heavily influenced by government expenditure, highlighting the importance of diversification for sustaining long-term growth and mitigating risks to the outlook. Improving competitiveness and productivity remains key to achieving broad-based long-term growth and reducing high structural unemployment. 


\section{Policy Discussions}

16. Against the background of the global economic crisis, the discussions focused on: preserving medium-term fiscal sustainability; the appropriate monetary and exchange rate policy stance; the status of the financial sector; and medium-term diversification.

\section{Box 3. Implementation of Previous Fund Policy Advice}

The authorities have generally agreed with Fund staff on Botswana's main economic challenges. During the 2007 Article IV consultation, staff recommended containing expenditure, strengthening non-diamond revenues, implementing recommendations from the 2007 FSAP and accelerating diversification. The authorities strengthened VAT collection in 2008/09, although implementation of the FSAP recommendations has been uneven. Public spending has increased significantly over the past two years owing to a large infrastructure investment plan to support diversification.

\section{A. Fiscal Policy}

\section{The substantial increase in expenditures during 2007/08 and 2008/09 raises} concerns about its quality. The staff, therefore, welcomed the authorities' intention to reduce expenditures from the original 2009/10 budget and focus on improving spending efficiency. Although spending will remain high even after the cuts, the authorities explained that the increase in development expenditure is largely temporary, and should decline in 2010/11 as ongoing infrastructure projects are completed. They also emphasized the exceptional circumstances facing the economy in 2009/10 due to the global economic downturn, and considered that the increase in spending would help mitigate the large contraction in the diamond sector. The authorities acknowledged that the wage bill had increased rapidly in recent years and pointed to recent measures to limit further growth, including the decision to forgo a cost of living adjustment in 2009/10. They also agreed that the recurrent costs associated with the completed infrastructure projects would add to pressure on current spending, and indicated that they are examining options for more costeffective public service delivery.

\section{The staff also recommended strengthening nonmining revenues over the} medium term given the considerable uncertainty surrounding mining and SACU revenues. In addition to strengthening tax administration, staff encouraged the authorities to consider raising the VAT and the fuel levy to regional rates over the medium term. The authorities indicated that raising the VAT was one of several options, but cautioned that the higher rate could undermine compliance and increase demand for exemptions. They observed, therefore, that for now they will concentrate on improving tax administration. 
19. Staff recommended that the authorities consider an alternative fiscal rule based on the NMPD as a share of nonmining GDP. The current fiscal rule sets a ceiling on overall expenditure of 40 percent of GDP. The NMPD provides a clearer picture of the underlying fiscal stance and is a better measure of longer-term fiscal sustainability and the government's ability to finance ongoing expenditures. The authorities noted they were considering revising their fiscal rule to incorporate a link to nonmining GDP, although this could be relative to expenditure rather than the level of NMPD. They indicated that such a revision to the fiscal rule could be introduced as part of National Development Plan 10 $(\mathrm{NDP} 10)^{4}$.

\section{Achieving fiscal sustainability would require reducing the NMPD to 8 percent in} the longer term, based on the permanent income hypothesis (PIH) (see Text Table 4, scenario (a)). ${ }^{5}$ To avoid sharp cuts in expenditures that could be destabilizing in the short and medium term, the staff encouraged the authorities to reduce the NMPD to at least 14 percent of nonmining GDP within the next five years (compared to the baseline projection of 17.8 percent in 2015/16). This would require keeping recurrent expenditures roughly constant in real terms, as development expenditures decline once current infrastructure projects are completed. The authorities did not identify a specific target for the NMPD, noting that there was still considerable need for spending to meet their development objectives, which could have a rate of return higher than savings in financial assets.

\section{To improve public expenditure management and increase spending efficiency,} staff encouraged the authorities to consider developing a Medium-Term Expenditure Framework (MTEF). The MTEF would provide a rolling three-year framework for implementing the six-year National Development Plans, in terms of which annual budgets would be formulated. The MTEF should be anchored in a regularly updated macroeconomic framework that would also provide the basis for growth and revenue forecasts - major weaknesses in the current process of budget formulation. The authorities indicated that improving the macroeconomic framework for budget preparation was a priority, and that they would welcome technical assistance in this area.

\footnotetext{
${ }^{4}$ NDP10 will be finalized later this year, to cover 2009-2016.

${ }^{5}$ The permanent income hypothesis argues in favor of saving excess receipts in order to smooth expenditures as mineral receipts decline over the medium term. In this model, permanent income is calculated by annuitizing the present value of expected future diamond revenues. The mission's calculations are based on keeping the annuity value constant as a share of nonmining GDP until mining-related wealth is exhausted in 2050.
} 
Text Table 4. Medium-Term Fiscal Outlook and Sustainability Benchmarks

\begin{tabular}{|c|c|c|c|c|}
\hline \multirow{3}{*}{ Staff projections $^{1}$} & \multicolumn{2}{|c|}{$\begin{array}{l}\text { Nonmining } \\
\text { Primary Balance }\end{array}$} & \multicolumn{2}{|c|}{ Overall Balance } \\
\hline & \multicolumn{2}{|c|}{$\begin{array}{c}\text { (Percent of } \\
\text { nonmining GDP) }\end{array}$} & \multicolumn{2}{|c|}{ (Percent of GDP) } \\
\hline & -28.3 & -17.8 & -11.1 & 0.0 \\
\hline $\begin{array}{l}\text { Sustainability benchmarks: } \\
\text { Revenue projections minus expenditure that follows " } \mathrm{P}\end{array}$ & anent" inco & & & \\
\hline $\begin{array}{l}\text { (a) Conservative assumptions } \\
\text { Baseline revenues }{ }^{1} \text { and conservative interest rate } \\
\text { assumption }\end{array}$ & -7.8 & -7.8 & 3.4 & 6.5 \\
\hline $\begin{array}{l}\text { (b) Less conservative assumptions } \\
\text { Baseline revenues and optimistic interest rate } \\
\text { assumption }\end{array}$ & -8.7 & -8.7 & 2.7 & 5.9 \\
\hline $\begin{array}{l}\text { (c) Optimistic assumptions } \\
\text { Optimistic mineral and non-mineral revenues and } \\
\text { optimistic interest rate assumption }\end{array}$ & -9.2 & -9.2 & 2.3 & 5.6 \\
\hline $\begin{array}{l}\text { (d) Back-loaded adjustment } \\
\text { Conservative assumptions }\end{array}$ & -12.3 & -9.9 & 0.0 & 5.1 \\
\hline
\end{tabular}

Source: IMF staff calculations.

${ }^{1}$ Revenue projections assume a slow increase in non-mineral revenues and a decrease in mineral revenues in terms of GDP. Expenditure projections assume that capital expenditure fall after 2010/11 and then stabilize over the medium term.

(a) Assumes a real interest rate of 3 percent. In comparison, the Norwegian Government Pension Fund has earned an annualized net real return of 4.6 percent since 1997.

(b) Assumes a real interest rate of about $4 \frac{1}{2}$ percent. Being more optimistic concerning the return on assets allows for somewhat larger non-mineral deficits and lower overall balances relative to (a).

(c) Assumes a slower decline in the path of mineral revenues after 2020; this changes the value of the annuity and thereby allows for higher non-mineral deficits relative to (b). This scenario also assumes stronger growth in non-mining revenues relative to (a) and (b).

(d) Programming the annuity to stay constant in real terms (rather than in terms of non-mining GDP) yields lower initial savings and assumes a more back-loaded adjustment. 


\section{B. Monetary and Exchange Rate Policies}

22. The authorities and staff agreed that there appears to be scope for the BoB to lower interest rates further provided that government spending in 2009/10 is scaled back as planned $^{6}$. Inflation is expected to continue to decline in line with projections for South Africa, from which Botswana imports most of its inflation. The authorities are mindful that too rapid an expansion in government spending after the large increase in 2008/09 could add to inflationary pressure and limit the scope for further interest rate cuts.

\section{The authorities indicated that the crawling peg regime has continued to serve}

Botswana well. They noted that they are continuing to strengthen their inflation forecasting model, but were not yet in a position to move to a full-fledged inflation-targeting framework. Staff noted that greater exchange rate flexibility would be required if the inflation objective were to become the primary monetary policy anchor over the medium-term.

\section{Staff's analysis suggests a modest overvaluation of the real exchange rate (Box}

4). In any event, there appears to be limited scope for real exchange rate adjustment to improve prospects for nonmining exports. The authorities broadly agreed with staff's assessment, and acknowledged that while ensuring stability of the REER is important to the competitiveness of Botswana's nonmining sector, other factors such as raising productivity by deepening structural reforms, and improving the business climate are also significant.

\footnotetext{
${ }^{6}$ Although the crawling peg remains the primary operational target, the lack of well-developed financial markets to permit full arbitrage has provided the authorities some scope to retain an independent interest rate policy.
} 


\section{Box 4. Exchange Rate and Competitiveness Assessment}

The assessment relies on three different but complementary approaches ${ }^{1}$ :

- An econometric analysis of determinants of the equilibrium real effective exchange rate (EREER), which takes into account the real interest rate differential between Botswana and its trading partners; the terms of trade; government consumption; and relative productivity against Botswana's main trading partners, indicates that Botswana's REER was overvalued by about 2 percent at the end of 2008 .

\section{Actual and Equilibrium Real Effective Exchange Rate \\ (Index, 2000=100)}

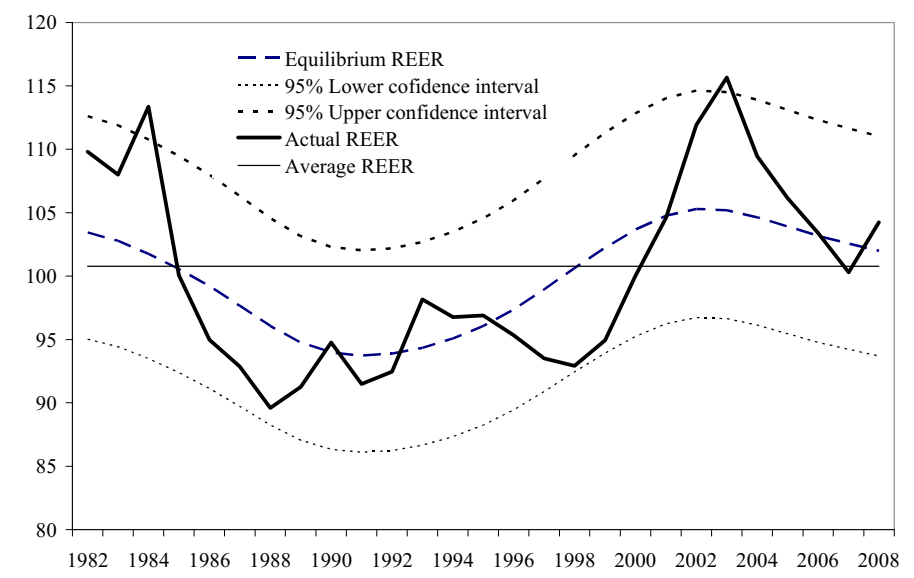

- A forward-looking assessment of external sustainability shows that by 2014 the projected current account surplus would be below its long-run sustainable level, suggesting an overvaluation of 3-6 percent, depending on the assumption used for trade elasticity, and highlighting the need for fiscal consolidation. A large part of the projected deficits in the interim reflect imports related to the two electricity projects.

\section{Current Account Sustainability (In percent of GDP)}

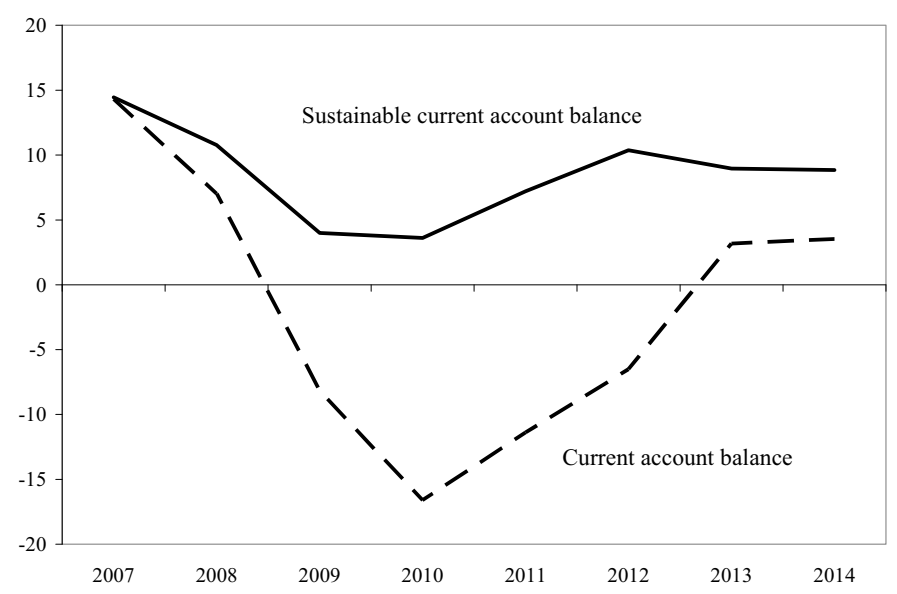

- Structural measures of competitiveness suggest that Botswana continues to lead most countries in the world in various aspects of governance, but faces declining labor productivity, high cost of trade across its borders, difficulties in business start-ups, and a travel and tourism industry that does not compete effectively in the region (Figure 5).

1/ For more details, see IMF Working Paper 08/83. 
Figure 5. Selected Competitiveness Indicators

Botswana scores well on measures of governance.

Botswana: Percentile ranking on Measures of Governance and Institutions ${ }^{1}$

\begin{tabular}{lccccccc}
\hline & $\begin{array}{c}\text { Voice \& } \\
\text { Accountability }\end{array}$ & $\begin{array}{c}\text { Political Stability \& } \\
\text { lack of violence }\end{array}$ & $\begin{array}{c}\text { Government } \\
\text { Effectiveness }\end{array}$ & $\begin{array}{c}\text { Regulatory } \\
\text { Quality }\end{array}$ & $\begin{array}{c}\text { Rule of } \\
\text { Law }\end{array}$ & $\begin{array}{c}\text { Control of } \\
\text { Corruption }\end{array}$ & Governance $^{2}$ \\
\hline 1996 & 73 & 71 & 67 & 77 & 70 & 69 & 71 \\
1998 & 71 & 75 & 73 & 74 & 68 & 77 & 73 \\
2000 & 72 & 79 & 73 & 72 & 68 & 76 & 73 \\
2002 & 69 & 75 & 75 & 76 & 67 & 75 & 73 \\
2003 & 72 & 82 & 75 & 75 & 69 & 84 & 76 \\
2004 & 75 & 78 & 77 & 69 & 69 & 82 & 75 \\
2005 & 70 & 83 & 75 & 69 & 68 & 83 & 75 \\
2006 & 63 & 80 & 72 & 66 & 68 & 79 & 71 \\
2007 & 93 & 78 & 73 & 65 & 70 & 80 & 77 \\
\hline
\end{tabular}

Source: World Bank Governance Indicators Data base

${ }^{1}$ Each entry shows percentile of countries that perform poorer than Botswana.

${ }^{2}$ Simple average of previous columns.

..or starting a business.

Ranking out of 181 countries Starting a business

Mauritius

South Africa

Chile

Seychelles

Malaysia

Botswana

Namibia

Lesotho

Swaziland

Source: World Bank's Doing Business 2009

Travel and tourism rank below regional leaders ...

Travel and Tourism Competitiveness Index 2008/09

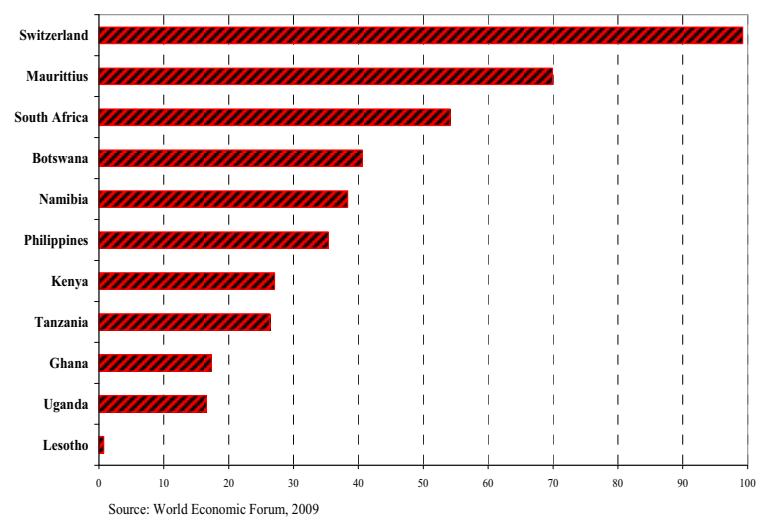

It also scores well in overall cost of doing business, but not in trading costs, licenses,...

Ranking out of 181 countries

Ease of Doing Business Rank 38

Trading Across Borders $\quad 149$

Dealing with Construction Permits $\quad 119$

Enforcing Contracts $\quad 92$

Starting a Business $\quad 80$

Employing Workers $\quad 73$

Getting Credit 43

Protecting Investors $\quad 38$

Registering Property $\quad 29$

Closing a Business $\quad 26$

Paying Taxes $\quad 17$

Source: World Bank's Doing Business 2009

However, it scores high among landlocked countries.

Ranking out of 38 countries

Ease of doing business in Landlocked countries

Switzerland

Austria

Azerbaijan

Slovakia

Botswana

Hungary

Luxumburg

Zambia

Swaziland

Uganda

Lesotho

Central African Republic

Source: World Bank's Doing Business 2009

... and declining labor productivity needs to be reversed.

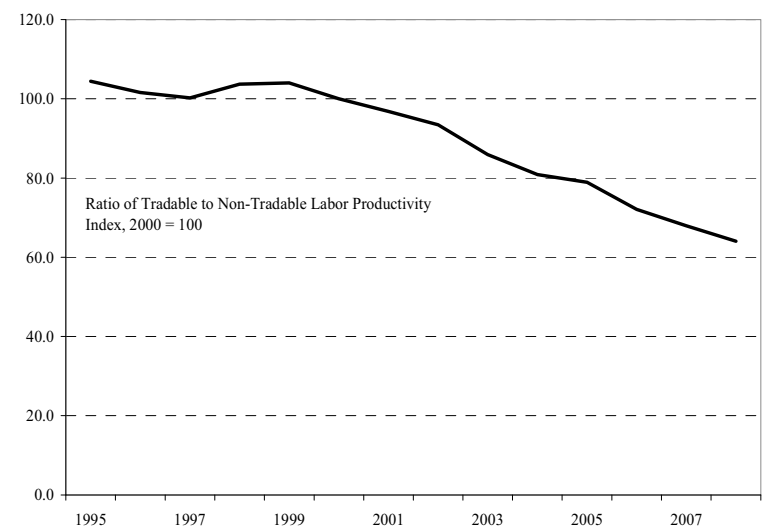




\section{Financial Sector}

25. To mitigate against risks from the deteriorating economy, banks have increased their provisioning, focused on lending to established clients and tightened the approval process for new clients. In the current environment, the authorities concurred with staff on the need for closer monitoring of loan portfolios and more frequent on-site inspections. In this context, they conduct routine stress tests and have developed guidelines on supervision of distressed banks.

\section{Progress on implementing the recommendations of the 2007 FSAP mission has}

been uneven (Box 5). There has been notable progress on supervision of the nonbanking financial sector. The Nonbank Financial Institutions Regulatory Authority (NBFIRA) began operating in April 2008 and the BoB is planning to transfer various supervisory responsibilities for nonbank financial institutions to the NBFIRA by end-2009. Looking ahead, the NBFIRA intends to embark on an ambitious reform agenda - including amending the insurance and pension acts, designing a risk-based framework for on-site inspection, and collecting and analyzing statutory returns for off-site inspections.

\section{Box 5. The 2007 FSAP Recommendations}

\section{Implementation of the recommendations has been uneven, but there are plans to} address most remaining issues:

- $\quad$ Systemic liquidity is being addressed by (i) increasing issuance of government debt and (ii) strengthening the liquidity forecasting framework.

- $\quad$ The authorities intend to amend the Banking Act to grant limited power to the BoB to vet "significant" and "controlling" shareholders.

- $\quad$ Cooperation with cross-border supervisors has improved, and internal guidelines have been drafted for dealing with problem banks and instituting contingency plans for crisis management.

- $\quad$ A Securities Bill is expected to be tabled in Parliament before end-2009.

- $\quad$ Anti-money laundering issues are being tackled through a Financial Intelligence Agency Bill that makes financing of terrorism a financial offence; the bill was approved by Parliament in April 2009 and is awaiting the President's signature. The BoB will be closely monitoring compliance as part of their effort to address recommendations from the 2007 World Bank AML/CFT mission. A Financial Intelligence Agency is to be established at the Ministry of Finance and Development Planning by end-2009.

- $\quad$ The BoB does not yet have full power to supervise stated-owned statutory banks, while legislation to improve the institutional basis and financial soundness of Saving and Credit Cooperatives is still to be updated. 


\section{Medium-Term Diversification}

27. The sharp diamond-related contraction in real GDP highlights the need for greater economic diversification. The current downturn offers a window of opportunity for accelerating the structural reforms needed to achieve these objectives. Key elements of the authorities' strategy for diversification are summarized in Box 6.

\section{Box 6. Economic Diversification}

The authorities' strategy for diversification centers on infrastructure investment to facilitate the development of key sectors:

- $\quad$ Mining and energy: The Diamond Hub seeks to increase value-added in downstream activities such as cutting, polishing, and jewelry making. In addition, the planned Morupule and Mmamabula power stations aim to take advantage of Botswana's coal deposits to meet domestic electricity demand and further diversify exports.

- $\quad$ Education and health: The authorities intend to strengthen human capital and productivity by improving access to education and the quality of tertiary instruction in key areas such as science, technology and medicine.

- Transport, agriculture and tourism: The Transport Hub aims to provide a corridor to Namibia and improve transport links to tourist areas. The Agricultural Hub aims to improve agricultural productivity and diversity. A number of new lodge sites have been awarded and the marketing activities of the Tourism Board expanded in order to support development of the tourist sector.

28. Strengthening the investment climate also remains a key priority. Staff encouraged the authorities to address structural aspects of competitiveness where Botswana lags behind other countries (Figure 5) and improve access to land and the provision of work permits for expatriates. Progress on privatization has been limited in recent years, but plans are underway to privatize the National Development Bank and revise the regulatory framework to facilitate privatization of several parastatals.

29. There has been some progress toward reducing the incidence of HIV/AIDS, but it remains a significant medium-term challenge. The authorities plan to further increase access to Anti-Retroviral (ARV) treatment, as well as expanding a campaign to raise public awareness. Reducing the high HIV/AIDS prevalence rate will be key to improving labor productivity.

\section{E. Data Issues}

30. Botswana has significantly improved the quality of economic statistics in recent years, but there is scope for further improvements, especially with regard to timeliness. 
31. Staff commended the considerable progress in the balance of payments and national accounts data and encouraged the authorities to complete the remaining steps necessary to move from the General Data Dissemination System (GDDS) to the Special Data Dissemination Standard (SDDS). The authorities emphasized their intention to move to SDDS, but indicated a need to further enhance capacity in order to be able to meet SDDS requirements on an ongoing basis.

\section{Staff Appraisal}

\section{Botswana's near-term macroeconomic outlook is uncertain, with significant}

downside risks. Diamond exports are expected to be sluggish through at least 2010, with large fiscal and external deficits likely to persist for the next several years. A protracted recovery in diamond demand would add to pressure on the external and fiscal positions. The two electricity generation projects should boost output as they come online in 2012-13, but the fall in diamond production expected after 2020 clouds the longer-term outlook.

33. The marked increase in expenditures in the last two years raises concerns about the quality of spending, as well as fiscal sustainability. A large part of the increase in expenditure reflects outlays for infrastructure investment, which should facilitate a return to a more sustainable level of spending as these projects are completed. The authorities will also need to rein in growth in the public sector wage bill, however, in order to create fiscal space for the recurrent costs associated with the completed projects. On current policies the fiscal position would deviate substantially from the recommended sustainability benchmark, suggesting the need for a larger than currently envisaged fiscal adjustment in the medium term.

\section{An alternative fiscal rule based on the NMPD as a share of nonmining GDP could} be considered. The NMPD provides a clearer picture of the underlying fiscal stance and is a better indicator of longer-term fiscal sustainability.

\section{The weak outlook for growth and easing of inflationary pressures should allow} further monetary policy easing in 2009. A further increase in international fuel prices could limit the downward trend in inflation, but domestic price pressures remain limited and food prices should continue to moderate. The limited scope for real exchange rate adjustment, given the large share of imported inflation, highlights the need for fiscal consolidation to ensure medium-term external stability.

36. The abrupt contraction in real GDP in $\mathbf{2 0 0 9}$ underscores the need for Botswana to accelerate greater economic diversification. The authorities have significantly increased spending on infrastructure, education and health, and it will be important to ensure that outcomes are commensurate with these additional expenditures. Moreover, it is critical to move quickly on key structural reforms to reduce the cost of doing business and enhance productivity

37. The global financial crisis has not had a significant adverse impact on the banking sector to date, but the authorities will need to remain vigilant. The sizable contraction in 2009 can be expected to increase stress on the banking system. The establishment of the 
NBFIRA is a welcome start, but further steps to enhance its capacity are essential, including through technical assistance, given the sizable reform agenda ahead. Remaining issues from the FSAP recommendations should also be addressed.

38. It is proposed that the next Article IV consultation be held on the standard 12-month cycle. 
Table 1. Medium-Term Economic and Financial Indicators, 2007-2014

\begin{tabular}{|c|c|c|c|c|c|c|c|c|}
\hline & 2007 & 2008 & 2009 & 2010 & 2011 & 2012 & 2013 & 2014 \\
\hline & \multicolumn{8}{|c|}{ (Annual percentage change, unless otherwise indicated) } \\
\hline \multicolumn{9}{|l|}{ National income and prices } \\
\hline Mineral & -2.0 & -3.7 & -36.7 & 0.3 & 24.0 & 29.1 & 1.8 & 0.1 \\
\hline Non-mineral & 9.0 & 7.2 & 4.9 & 5.5 & 3.5 & 7.7 & 12.3 & 2.8 \\
\hline Consumer prices (average) & 7.1 & 12.6 & 8.7 & 6.5 & 5.9 & 5.4 & 5.2 & 5.1 \\
\hline Consumer prices (end of period) & 8.1 & 13.7 & 7.0 & 6.1 & 5.7 & 5.3 & 5.2 & 5.0 \\
\hline Nominal GDP (billions of pula) $1 /$ & 75.7 & 91.2 & 80.1 & 87.1 & 98.1 & 116.8 & 133.9 & 142.5 \\
\hline Mineral & 30.6 & 37.6 & 20.3 & 21.7 & 29.8 & 41.1 & 44.5 & 47.3 \\
\hline Non-mineral 2/ & 45.2 & 53.6 & 59.8 & 65.4 & 68.2 & 75.7 & 89.4 & 95.2 \\
\hline Diamond production (millions of carats) & 33.6 & 32.6 & 20.0 & 20.0 & 25.0 & 32.6 & 33.0 & 33.0 \\
\hline \multicolumn{9}{|l|}{ External sector } \\
\hline Exports of goods and services, f.o.b. (US\$) & 10.6 & -0.4 & -35.8 & 5.3 & 16.9 & 19.3 & 22.9 & 3.8 \\
\hline \multicolumn{9}{|l|}{ Of which: } \\
\hline Diamonds & -2.3 & -6.1 & -44.6 & 1.8 & 30.3 & 32.2 & 2.8 & 1.5 \\
\hline Other & 29.2 & 56.5 & -22.3 & 9.4 & 6.7 & 6.6 & 105.2 & 7.7 \\
\hline Imports of goods and services, f.o.b. (US\$) & 29.2 & 26.2 & -6.6 & 23.6 & 1.7 & 4.9 & -3.3 & 3.2 \\
\hline Terms of trade & 1.0 & 7.9 & -16.5 & -0.3 & -1.9 & 0.2 & 0.4 & 0.4 \\
\hline \multicolumn{9}{|l|}{ Central government finance $3 /$} \\
\hline Total revenue and grants & 4.5 & 5.7 & -13.1 & 12.5 & 16.4 & 16.3 & 9.9 & 6.4 \\
\hline Total expenditure and net lending & 25.8 & 40.6 & 1.4 & 8.4 & 2.0 & 6.9 & 6.4 & 6.3 \\
\hline \multicolumn{9}{|l|}{ Money and banking } \\
\hline Net foreign assets & 24.1 & 20.2 & 0.6 & 5.3 & 8.4 & 5.3 & 7.2 & 6.7 \\
\hline Net domestic assets & 17.0 & 19.1 & -15.8 & -9.0 & 0.6 & -7.2 & 0.3 & -12.0 \\
\hline Money and quasi money (M2) & 31.2 & 21.1 & 14.9 & 14.5 & 12.3 & 10.9 & 9.8 & 13.2 \\
\hline Velocity (non-mineral GDP relative to $\mathrm{M} 2$ ) & 1.4 & 1.4 & 1.3 & 1.3 & 1.2 & 1.2 & 1.3 & 1.2 \\
\hline \multirow[t]{2}{*}{ Credit to the private sector } & 25.7 & 26.6 & 14.0 & 9.7 & 8.6 & 7.8 & 7.7 & 7.5 \\
\hline & \multicolumn{8}{|c|}{ (Percent of GDP, unless otherwise indicated) } \\
\hline \multicolumn{9}{|l|}{ Investment and savings $1 /$} \\
\hline Gross investment & 25.9 & 32.4 & 35.8 & 44.2 & 40.8 & 40.1 & 31.5 & 30.8 \\
\hline Public & 7.8 & 11.2 & 13.0 & 12.1 & 9.5 & 7.9 & 7.3 & 7.3 \\
\hline Public & 20.1 & 15.0 & 12.4 & 11.4 & 12.7 & 13.9 & 14.3 & 14.6 \\
\hline Private & 20.8 & 27.1 & 15.2 & 16.2 & 16.7 & 19.7 & 20.4 & 19.8 \\
\hline Saving-investment balance & 15.0 & 9.6 & -8.2 & -16.6 & -11.4 & -6.5 & 3.2 & 3.5 \\
\hline \multicolumn{9}{|l|}{ Central government finance $3 /$} \\
\hline Total revenue and grants & 36.0 & 34.2 & 32.2 & 33.0 & 33.6 & 33.1 & 32.4 & 32.4 \\
\hline Total expenditure and net lending & 31.2 & 39.5 & 43.2 & 42.7 & 38.0 & 34.5 & 32.7 & 32.6 \\
\hline Overall balance (deficit -) & 4.8 & -5.2 & -11.1 & -9.7 & -4.5 & -1.4 & -0.3 & -0.3 \\
\hline Non-mineral primary balance (percent of non-mineral GDP & -16.8 & -28.6 & -28.3 & -26.7 & -23.4 & -21.4 & -18.6 & -18.5 \\
\hline \multicolumn{9}{|l|}{ External sector } \\
\hline Current account balance & 14.3 & 7.0 & -8.2 & -16.6 & -11.4 & -6.5 & 3.2 & 3.5 \\
\hline Balance of payments & 14.1 & 8.2 & 0.9 & -2.1 & 2.3 & -0.1 & 1.4 & 1.6 \\
\hline External public debt $5 /$ & 2.5 & 2.3 & 11.7 & 16.1 & 15.0 & 13.3 & 12.1 & 11.4 \\
\hline \multirow[t]{2}{*}{ External public debt in percent of total exports } & 5.3 & 5.3 & 33.2 & 45.0 & 38.1 & 32.0 & 26.1 & 24.2 \\
\hline & \multicolumn{8}{|c|}{ (US\$ millions, unless otherwise indicated) } \\
\hline Change in reserves (increase -) & $-1,742$ & $-1,100$ & -95 & 231 & -268 & 7 & -202 & -232 \\
\hline Gross official reserves (end of period) & 9,743 & 9,125 & 9,220 & 8,988 & 9,256 & 9,249 & 9,450 & 9,682 \\
\hline In months of imports of goods and services $6 /$ & 20.7 & 20.8 & 17.0 & 16.3 & 16.0 & 16.5 & 16.4 & 16.3 \\
\hline In percent of GDP & 79.0 & 67.8 & 86.8 & 81.1 & 78.9 & 69.4 & 64.7 & 64.9 \\
\hline Pula Fund (US\$ millions) & 6,614 & 6,866 & $\ldots$ & $\ldots$ & $\ldots$ & $\ldots$ & $\ldots$ & $\ldots$ \\
\hline In months of imports of goods and services $6 /$ & 14.1 & 15.6 & $\ldots$ & $\ldots$ & $\ldots$ & $\ldots$ & $\ldots$ & $\ldots$ \\
\hline Liquidity portfolio/ other reserves (US\$ millions) & 3,130 & 2,259 & $\ldots$ & $\ldots$ & $\ldots$ & $\ldots$ & $\ldots$ & $\ldots$ \\
\hline In months of imports of goods and services $6 /$ & 6.6 & 5.1 & $\cdots$ & $\cdots$ & $\cdots$ & $\cdots$ & $\ldots$ & $\ldots$ \\
\hline Gross official reserves, net of BoBC (US\$ millions) & 6,977 & 6,790 & $\begin{array}{l}\cdots \\
\cdots\end{array}$ & $\begin{array}{l}\cdots \\
\ldots\end{array}$ & $\begin{array}{l}\cdots \\
\ldots\end{array}$ & $\begin{array}{l}\cdots \\
\cdots\end{array}$ & $\begin{array}{l}\cdots \\
\cdots\end{array}$ & $\begin{array}{l}\cdots \\
\ldots\end{array}$ \\
\hline In months of imports of goods and services $6 /$ & 14.8 & 15.5 & $\ldots$ & $\ldots$ & $\ldots$ & $\ldots$ & $\ldots$ & $\ldots$ \\
\hline
\end{tabular}

Sources: Botswana authorities; and IMF staff estimates and projections.

1/ Calendar year.

2/ Stronger growth in non-mineral real GDP over the medium-term partly reflects significant investment in electricity generation, including the Morupule Power Station and the Mmamabula Energy Project.

3/ Year beginning April 1.

4/ The non-mineral primary balance is computed as the difference between non-mineral revenue and expenditure (excluding interest receipts and interest payments), divided by non-mineral GDP.

5/ Medium- and long-term public and publicly guaranteed debt outstanding.

$6 /$ Based on imports of goods and services for the following year. 
Table 2. Sectoral GDP and Savings-Investment Balances, 2007-2014 1/

\begin{tabular}{|c|c|c|c|c|c|c|c|c|}
\hline & 2007 & 2008 & 2009 & 2010 & 2011 & 2012 & 2013 & 2014 \\
\hline & \multicolumn{8}{|c|}{ (Millions of pula) } \\
\hline Consumption & 46,969 & 57,858 & 62,857 & 68,767 & 74,852 & 82,480 & 91,181 & 97,597 \\
\hline Public & 14,726 & 18,185 & 19,556 & 21,265 & 23,436 & 25,287 & 26,934 & 28,605 \\
\hline Private & 32,243 & 39,674 & 43,302 & 47,502 & 51,417 & 57,193 & 64,247 & 68,991 \\
\hline Gross investment & 19,614 & 29,596 & 28,663 & 38,494 & 39,984 & 46,834 & 42,154 & 43,919 \\
\hline Public & 5,925 & 10,200 & 10,377 & 10,523 & 9,284 & 9,239 & 9,819 & 10,421 \\
\hline Private (including changes in stocks) & 13,689 & 19,396 & 18,286 & 27,971 & 30,699 & 37,595 & 32,335 & 33,498 \\
\hline Net exports of goods and services $2 /$ & 9,145 & 3,759 & $-11,433$ & $-20,132$ & $-16,747$ & $-12,562$ & 550 & 973 \\
\hline Exports of goods and services & 36,057 & 42,140 & 28,333 & 31,113 & 38,680 & 48,348 & 62,104 & 67,242 \\
\hline Imports of goods and services & $-26,912$ & $-38,381$ & $-39,766$ & $-51,244$ & $-55,427$ & $-60,910$ & $-61,554$ & $-66,270$ \\
\hline Gross domestic savings & 28,759 & 33,355 & 17,229 & 18,362 & 23,237 & 34,272 & 42,703 & 44,891 \\
\hline Public & 7,162 & 5,221 & 2,273 & 1,898 & 4,074 & 7,310 & 9,325 & 10,214 \\
\hline Private & 21,597 & 28,134 & 14,956 & 16,465 & 19,162 & 26,962 & 33,378 & 34,677 \\
\hline \multirow[t]{2}{*}{ GDP at market prices } & 75,728 & 91,213 & 80,087 & 87,130 & 98,089 & 116,752 & 133,885 & 142,488 \\
\hline & \multicolumn{8}{|c|}{ (Percent of GDP) } \\
\hline Consumption & 62.0 & 63.4 & 78.5 & 78.9 & 76.3 & 70.6 & 68.1 & 68.5 \\
\hline Public & 19.4 & 19.9 & 24.4 & 24.4 & 23.9 & 21.7 & 20.1 & 20.1 \\
\hline Private & 42.6 & 43.5 & 54.1 & 54.5 & 52.4 & 49.0 & 48.0 & 48.4 \\
\hline Gross investment & 25.9 & 32.4 & 35.8 & 44.2 & 40.8 & 40.1 & 31.5 & 30.8 \\
\hline Public & 7.8 & 11.2 & 13.0 & 12.1 & 9.5 & 7.9 & 7.3 & 7.3 \\
\hline Private (including changes in stock) & 18.1 & 21.3 & 22.8 & 32.1 & 31.3 & 32.2 & 24.2 & 23.5 \\
\hline Net exports of goods and services & 12.1 & 4.1 & -14.3 & -23.1 & -17.1 & -10.8 & 0.4 & 0.7 \\
\hline Exports of goods and services & 47.6 & 46.2 & 35.4 & 35.7 & 39.4 & 41.4 & 46.4 & 47.2 \\
\hline Imports of goods and services & -35.5 & -42.1 & -49.7 & -58.8 & -56.5 & -52.2 & -46.0 & -46.5 \\
\hline Gross domestic savings & 38.0 & 36.6 & 21.5 & 21.1 & 23.7 & 29.4 & 31.9 & 31.5 \\
\hline Public & 9.5 & 5.7 & 2.8 & 2.2 & 4.2 & 6.3 & 7.0 & 7.2 \\
\hline \multirow[t]{2}{*}{ Private } & 28.5 & 30.8 & 18.7 & 18.9 & 19.5 & 23.1 & 24.9 & 24.3 \\
\hline & \multicolumn{8}{|c|}{ (Annual percentage change, unless otherwise indicated) } \\
\hline Real GDP & 4.4 & 2.9 & -10.3 & 4.1 & 8.6 & 13.8 & 8.9 & 2.0 \\
\hline Of which: non-mineral real GDP & 9.0 & 7.2 & 4.9 & 5.5 & 3.5 & 7.7 & 12.3 & 2.8 \\
\hline Nominal GDP (billions of pula) & 75.7 & 91.2 & 80.1 & 87.1 & 98.1 & 116.8 & 133.9 & 142.5 \\
\hline Mineral & 30.6 & 37.6 & 20.3 & 21.7 & 29.8 & 41.1 & 44.5 & 47.3 \\
\hline Non-mineral 2/ & 45.2 & 53.6 & 59.8 & 65.4 & 68.2 & 75.7 & 89.4 & 95.2 \\
\hline Consumer prices (end of period) & 8.1 & 13.7 & 7.0 & 6.1 & 5.7 & 5.3 & 5.2 & 5.0 \\
\hline
\end{tabular}

Sources: Central Statistics Office; and IMF staff estimates.

1/ National accounts data is now presented on a calendar year basis, rather than based on a year beginning July 1 as was the previous convention. 2/ Stronger growth in non-mineral real GDP over the medium-term largely reflects significant investment in electricity generation, including the Morupule Power Station and the Mmamabula Energy Project. 
Table 3. Balance of Payments, 2007-2014 1/

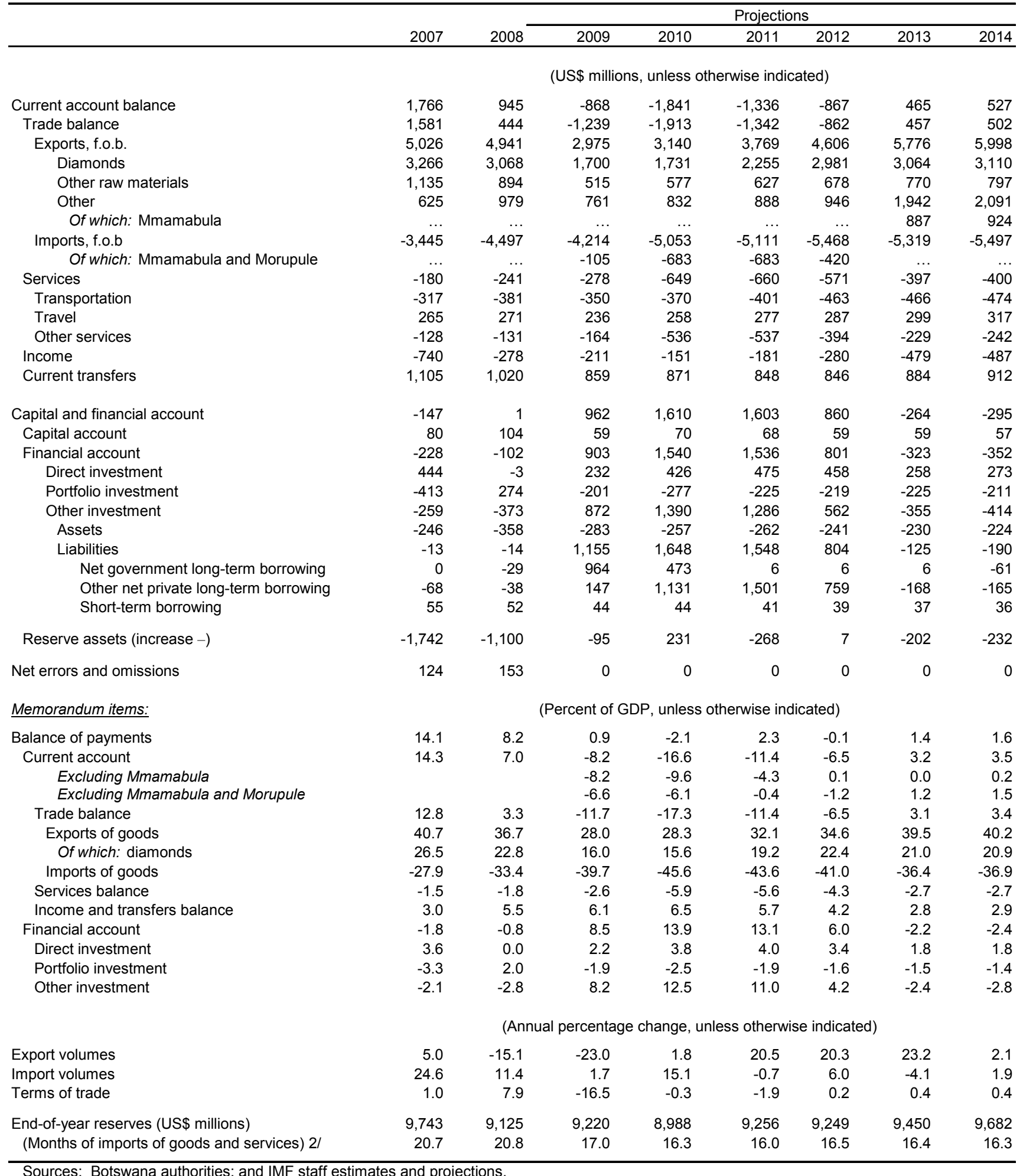

1/ Based on pula-denominated estimates converted at period-average exchange rate.

$2 /$ Based on imports of goods and services for the following year. 
Table 4a. Central Government Operations, 2007/08-2013/14 1/

\begin{tabular}{|c|c|c|c|c|c|c|c|c|}
\hline & \multirow[t]{2}{*}{ 2007/08 } & \multirow{2}{*}{$\frac{2008 / 09}{\text { Preliminary }}$} & \multicolumn{2}{|c|}{$2009 / 10$} & \multirow[t]{2}{*}{$2010 / 11$} & \multirow[t]{2}{*}{$2011 / 12$} & \multirow[t]{2}{*}{$2012 / 13$} & \multirow[t]{2}{*}{$2013 / 14$} \\
\hline & & & Budget & Projection & & & & \\
\hline & \multicolumn{8}{|c|}{ (Millions of pula) } \\
\hline Total revenue and grants & 28,629 & 30,269 & 24,393 & 26,316 & 29,613 & 34,475 & 40,085 & 44,059 \\
\hline Total revenue & 28,052 & 29,508 & 24,080 & 26,003 & 29,275 & 34,116 & 39,680 & 43,594 \\
\hline Tax revenue & 17,267 & 20,176 & 16,307 & 17,974 & 20,391 & 22,797 & 25,621 & 28,264 \\
\hline Income taxes & 6,342 & 7,906 & 5,722 & 6,752 & 7,633 & 9,202 & 10,993 & 12,239 \\
\hline Mineral & 2,448 & 3,451 & 1,983 & 2,423 & 2,760 & 3,825 & 4,924 & 5,269 \\
\hline Non-mineral & 3,894 & 4,454 & 3,739 & 4,329 & 4,873 & 5,377 & 6,069 & 6,970 \\
\hline Taxes on goods and services $2 /$ & 2,852 & 4,256 & 3,255 & 3,864 & 4,569 & 5,196 & 5,579 & 5,991 \\
\hline Customs Union receipts 3/ & 7,835 & 7,750 & 7,065 & 7,065 & 7,872 & 8,063 & 8,671 & 9,598 \\
\hline Other & 238 & 264 & 265 & 293 & 316 & 336 & 379 & 435 \\
\hline Nontax revenue & 10,785 & 9,332 & 7,773 & 8,029 & 8,884 & 11,320 & 14,059 & 15,331 \\
\hline Mineral royalties and dividends & 8,564 & 6,725 & 4,852 & 5,108 & 5,818 & 8,063 & 10,380 & 11,107 \\
\hline Interest & 67 & 51 & 60 & 60 & 65 & 75 & 88 & 99 \\
\hline Property income & 1,125 & 1,533 & 1,171 & 1,171 & 1,175 & 1,246 & 1,406 & 1,615 \\
\hline Of which: BoB transfers & 906 & 1,302 & 1,000 & 1,000 & 899 & 1,028 & 1,210 & 1,360 \\
\hline Fees and charges & 1,029 & 1,024 & 1,690 & 1,690 & 1,825 & 1,936 & 2,185 & 2,509 \\
\hline Grants & 577 & 761 & 313 & 313 & 338 & 359 & 405 & 465 \\
\hline Total expenditure and net lending & 24,822 & 34,894 & 37,787 & 35,365 & 38,340 & 39,093 & 41,798 & 44,475 \\
\hline Current expenditure & 18,579 & 23,686 & 27,357 & 25,463 & 27,789 & 30,420 & 32,571 & 34,670 \\
\hline Wages and salaries & 6,850 & 8,692 & 9,576 & 8,906 & 9,623 & 10,334 & 11,045 & 11,789 \\
\hline Interest & 248 & 369 & 300 & 300 & 601 & 1,224 & 1,366 & 1,360 \\
\hline Other & 11,480 & 14,625 & 17,481 & 16,257 & 17,565 & 18,863 & 20,160 & 21,520 \\
\hline Of which: grants and subsidies & 4,869 & 7,058 & 8,436 & 7,846 & 8,477 & 9,103 & 9,729 & 10,386 \\
\hline Capital expenditure & 6,548 & 11,417 & 10,558 & 10,030 & 10,687 & 8,817 & 9,379 & 9,965 \\
\hline Net lending & -305 & -209 & -128 & -128 & -136 & -144 & -152 & -160 \\
\hline Overall balance & 3,808 & $-4,625$ & $-13,394$ & $-9,049$ & $-8,727$ & $-4,618$ & $-1,713$ & -416 \\
\hline Financing & $-3,808$ & 4,625 & 13,394 & 9,049 & 8,727 & 4,618 & 1,713 & 416 \\
\hline Foreign (net) & -93 & -313 & 103 & 10,992 & -7 & -7 & -7 & -7 \\
\hline Domestic & $-3,714$ & 4,938 & 13,292 & $-1,943$ & 8,734 & 4,625 & 1,720 & 423 \\
\hline \multicolumn{9}{|l|}{ Memorandum items: } \\
\hline Non-mineral primary balance 4/ & $-7,929$ & $-15,784$ & $-20,989$ & $-17,340$ & $-17,668$ & $-16,384$ & $-16,949$ & $-16,891$ \\
\hline
\end{tabular}

Sources: Ministry of Finance and Development Planning; and IMF staff estimates and projections.

1/ Fiscal year begins on April 1.

2/ Refers to sales tax and VAT.

3/ SACU receipts consist of external trade and excises on imported goods as well as a development component derived from excises.

4/ The non-mineral primary balance is computed as the difference between non-mineral revenue and expenditure (excluding interest payments and receipts, which are roughly proxied by BoB transfers and interest). 
Table 4b. Central Government Operations, 2007/08-2013/14 1/

\begin{tabular}{|c|c|c|c|c|c|c|c|c|}
\hline & \multirow[t]{2}{*}{$2007 / 08$} & \multirow{2}{*}{$\frac{2008 / 09}{\text { Preliminary }}$} & \multicolumn{2}{|c|}{$2009 / 10$} & \multirow[t]{2}{*}{$2010 / 11$} & \multirow[t]{2}{*}{$2011 / 12$} & \multirow[t]{2}{*}{$2012 / 13$} & \multirow[t]{2}{*}{$2013 / 14$} \\
\hline & & & Budget & Projection & & & & \\
\hline & \multicolumn{8}{|c|}{ (Percent of GDP) } \\
\hline Total revenue and grants & 36.0 & 34.2 & 25.4 & 32.2 & 33.0 & 33.6 & 33.1 & 32.4 \\
\hline Total revenue & 35.2 & 33.4 & 25.1 & 31.8 & 32.6 & 33.2 & 32.8 & 32.0 \\
\hline Tax revenue & 21.7 & 22.8 & 17.0 & 22.0 & 22.7 & 22.2 & 21.2 & 20.8 \\
\hline Income taxes & 8.0 & 8.9 & 6.0 & 8.2 & 8.5 & 9.0 & 9.1 & 9.0 \\
\hline Mineral & 3.1 & 3.9 & 2.1 & 3.0 & 3.1 & 3.7 & 4.1 & 3.9 \\
\hline Non-mineral & 4.9 & 5.0 & 3.9 & 5.3 & 5.4 & 5.2 & 5.0 & 5.1 \\
\hline Taxes on goods and services $2 /$ & 3.6 & 4.8 & 3.4 & 4.7 & 5.1 & 5.1 & 4.6 & 4.4 \\
\hline Customs Union receipts $3 /$ & 9.8 & 8.8 & 7.4 & 8.6 & 8.8 & 7.8 & 7.2 & 7.1 \\
\hline Other & 0.3 & 0.3 & 0.3 & 0.4 & 0.4 & 0.3 & 0.3 & 0.3 \\
\hline Nontax revenue & 13.5 & 10.6 & 8.1 & 9.8 & 9.9 & 11.0 & 11.6 & 11.3 \\
\hline Mineral royalties and dividends & 10.8 & 7.6 & 5.1 & 6.2 & 6.5 & 7.8 & 8.6 & 8.2 \\
\hline Interest & 0.1 & 0.1 & 0.1 & 0.1 & 0.1 & 0.1 & 0.1 & 0.1 \\
\hline Property income & 1.4 & 1.7 & 1.2 & 1.4 & 1.3 & 1.2 & 1.2 & 1.2 \\
\hline Of which: BoB transfers & 1.1 & 1.5 & 1.0 & 1.2 & 1.0 & 1.0 & 1.0 & 1.0 \\
\hline Fees and charges & 1.3 & 1.2 & 1.8 & 2.1 & 2.0 & 1.9 & 1.8 & 1.8 \\
\hline Grants & 0.7 & 0.9 & 0.3 & 0.4 & 0.4 & 0.3 & 0.3 & 0.3 \\
\hline Total expenditure and net lending & 31.2 & 39.5 & 39.4 & 43.2 & 42.7 & 38.0 & 34.5 & 32.7 \\
\hline Current expenditure & 23.3 & 26.8 & 28.5 & 31.1 & 30.9 & 29.6 & 26.9 & 25.5 \\
\hline Wages and salaries & 8.6 & 9.8 & 10.0 & 10.9 & 10.7 & 10.1 & 9.1 & 8.7 \\
\hline Interest & 0.3 & 0.4 & 0.3 & 0.4 & 0.7 & 1.2 & 1.1 & 1.0 \\
\hline Other & 14.4 & 16.5 & 18.2 & 19.9 & 19.5 & 18.4 & 16.7 & 15.8 \\
\hline Of which: grants and subsidies & 6.1 & 8.0 & 8.8 & 9.6 & 9.4 & 8.9 & 8.0 & 7.6 \\
\hline Capital expenditure & 8.2 & 12.9 & 11.0 & 12.3 & 11.9 & 8.6 & 7.7 & 7.3 \\
\hline Net lending & -0.4 & -0.2 & -0.1 & -0.2 & -0.2 & -0.1 & -0.1 & -0.1 \\
\hline Overall balance & 4.8 & -5.2 & -14.0 & -11.1 & -9.7 & -4.5 & -1.4 & -0.3 \\
\hline Financing & -4.8 & 5.2 & 14.0 & 11.1 & 9.7 & 4.5 & 1.4 & 0.3 \\
\hline Foreign (net) & -0.1 & -0.4 & 0.1 & 13.4 & 0.0 & 0.0 & 0.0 & 0.0 \\
\hline Domestic & -4.7 & 5.6 & 13.8 & -2.4 & 9.7 & 4.5 & 1.4 & 0.3 \\
\hline \multicolumn{9}{|l|}{ Memorandum items: } \\
\hline $\begin{array}{r}\text { Non-mineral primary balance 4/ } \\
\text { (percent of non-mineral GDP) }\end{array}$ & -16.8 & -28.6 & -34.3 & -28.3 & -26.7 & -23.4 & -21.4 & -18.6 \\
\hline GDP (fiscal year; millions of pula) & 79,599 & 88,431 & 96,000 & 81,848 & 89,870 & 102,754 & 121,035 & 136,036 \\
\hline
\end{tabular}

Sources: Ministry of Finance and Development Planning; and IMF staff estimates and projections.

1/ Fiscal year begins on April 1.

2/ Refers to sales tax and VAT.

3/ SACU receipts consist of external trade and excises on imported goods as well as a development component derived from excises.

4/ The non-mineral primary balance is computed as the difference between non-mineral revenue and expenditure (excluding interest payments and receipts, which are roughly proxied by BoB transfers and interest). 
Table 4c. Central Government Operations, 2007/08-2013/14 1/

\begin{tabular}{|c|c|c|c|c|c|c|c|c|}
\hline & $2006 / 07$ & $2007 / 08$ & $\frac{2008 / 09}{\text { Preliminary }}$ & $\frac{2009 / 10}{\text { Projection }}$ & $2010 / 11$ & $2011 / 12$ & $2012 / 13$ & $2013 / 14$ \\
\hline & & \multicolumn{7}{|c|}{ (Percent of non-mining GDP) } \\
\hline Total revenue and grants & 69.1 & 60.5 & 54.8 & 43.0 & 44.8 & 49.2 & 50.7 & 48.5 \\
\hline Total revenue & 68.0 & 59.3 & 53.5 & 42.5 & 44.3 & 48.7 & 50.2 & 48.0 \\
\hline Tax revenue & 40.2 & 36.5 & 36.6 & 29.4 & 30.8 & 32.5 & 32.4 & 31.1 \\
\hline Income taxes & 17.3 & 13.4 & 14.3 & 11.0 & 11.5 & 13.1 & 13.9 & 13.5 \\
\hline Mineral & 9.6 & 5.2 & 6.3 & 4.0 & 4.2 & 5.5 & 6.2 & 5.8 \\
\hline Non-mineral & 7.8 & 8.2 & 8.1 & 7.1 & 7.4 & 7.7 & 7.7 & 7.7 \\
\hline Taxes on goods and services $2 /$ & 5.7 & 6.0 & 7.7 & 6.3 & 6.9 & 7.4 & 7.1 & 6.6 \\
\hline Customs Union receipts 3/ & 16.7 & 16.6 & 14.0 & 11.5 & 11.9 & 11.5 & 11.0 & 10.6 \\
\hline Other & 0.5 & 0.5 & 0.5 & 0.5 & 0.5 & 0.5 & 0.5 & 0.5 \\
\hline Nontax revenue & 27.8 & 22.8 & 16.9 & 13.1 & 13.4 & 16.1 & 17.8 & 16.9 \\
\hline Mineral royalties and dividends & 23.5 & 18.1 & 12.2 & 8.3 & 8.8 & 11.5 & 13.1 & 12.2 \\
\hline Interest & 0.1 & 0.1 & 0.1 & 0.1 & 0.1 & 0.1 & 0.1 & 0.1 \\
\hline Property income & 1.6 & 2.4 & 2.8 & 1.9 & 1.8 & 1.8 & 1.8 & 1.8 \\
\hline Of which: BoB transfers & 1.4 & 1.9 & 2.4 & 1.6 & 1.4 & 1.5 & 1.5 & 1.5 \\
\hline Fees and charges & 2.5 & 2.2 & 1.9 & 2.8 & 2.8 & 2.8 & 2.8 & 2.8 \\
\hline Grants & 1.1 & 1.2 & 1.4 & 0.5 & 0.5 & 0.5 & 0.5 & 0.5 \\
\hline Total expenditure and net lending & 49.8 & 52.5 & 63.2 & 57.8 & 58.0 & 55.8 & 52.8 & 48.9 \\
\hline Current expenditure & 40.3 & 39.3 & 42.9 & 41.6 & 42.0 & 43.4 & 41.2 & 38.2 \\
\hline Wages and salaries & 14.6 & 14.5 & 15.7 & 14.5 & 14.6 & 14.7 & 14.0 & 13.0 \\
\hline Interest & 0.6 & 0.5 & 0.7 & 0.5 & 0.9 & 1.7 & 1.7 & 1.5 \\
\hline Other & 25.0 & 24.3 & 26.5 & 26.6 & 26.6 & 26.9 & 25.5 & 23.7 \\
\hline Of which: grants and subsidies & 11.1 & 10.3 & 12.8 & 12.8 & 12.8 & 13.0 & 12.3 & 11.4 \\
\hline Capital expenditure & 10.2 & 13.8 & 20.7 & 16.4 & 16.2 & 12.6 & 11.9 & 11.0 \\
\hline Net lending & -0.7 & -0.6 & -0.4 & -0.2 & -0.2 & -0.2 & -0.2 & -0.2 \\
\hline Overall balance & 19.3 & 8.1 & -8.4 & -14.8 & -13.2 & -6.6 & -2.2 & -0.5 \\
\hline \multicolumn{9}{|l|}{ Memorandum items: } \\
\hline Non-mineral revenue & 36.0 & 37.3 & 36.4 & 30.7 & 31.8 & 32.2 & 31.3 & 30.5 \\
\hline Non-mineral primary balance 4/ & -14.8 & -16.8 & -28.6 & -28.3 & -26.7 & -23.4 & -21.4 & -18.6 \\
\hline Non-mineral GDP (fiscal year; millions of pula) & 39,626 & 47,284 & 55,191 & 61,219 & 66,110 & 70,102 & 79,116 & 90,866 \\
\hline
\end{tabular}

Sources: Ministry of Finance and Development Planning; and IMF staff estimates and projections.

1/ Fiscal year begins on April 1.

2/ Refers to sales tax and VAT.

3/ SACU receipts consist of external trade and excises on imported goods as well as a development component derived from excises.

4/ The non-mineral primary balance is computed as the difference between non-mineral revenue and expenditure (excluding interest payments and receipts, which are roughly proxied by BoB transfers and interest). 
Table 5. Monetary Survey, 2004-2009 1/

\begin{tabular}{|c|c|c|c|c|c|c|}
\hline & 2004 & 2005 & 2006 & 2007 & 2008 & $\begin{array}{l}2009 \\
\text { riv]. }\end{array}$ \\
\hline & \multicolumn{6}{|c|}{ (Millions of pula, end of period) } \\
\hline Net foreign assets & 25,269 & 35,903 & 48,812 & 60,589 & 72,831 & 73,283 \\
\hline Bank of Botswana & 24,001 & 34,372 & 47,720 & 58,392 & 68,414 & 69,614 \\
\hline Assets & 24,106 & 34,491 & 47,839 & 58,518 & 68,541 & 69,725 \\
\hline Liabilities & 108 & 118 & 123 & 126 & 127 & 111 \\
\hline Commercial banks & 1,268 & 1,531 & 1,093 & 2,177 & 4,416 & 3,668 \\
\hline Assets & 1,779 & 2,993 & 2,863 & 3,751 & 6,059 & 5,320 \\
\hline Liabilities & 511 & 1,462 & 1,771 & 1,574 & 1,642 & 1,652 \\
\hline Net other foreign assets & 3 & -1 & 4 & 20 & 1 & 1 \\
\hline Net domestic assets & $-5,560$ & $-13,356$ & $-24,245$ & $-28,364$ & $-33,792$ & $-28,441$ \\
\hline Net domestic credit & -452 & $-3,410$ & $-9,878$ & $-13,656$ & $-11,721$ & $-8,264$ \\
\hline Net claims on the government & $-10,045$ & $-13,703$ & $-22,246$ & $-27,833$ & $-29,730$ & $-29,129$ \\
\hline Bank of Botswana & $-9,541$ & $-13,223$ & $-21,236$ & $-27,871$ & $-31,768$ & $-30,919$ \\
\hline Commercial banks & 31 & 62 & 12 & 38 & 2,038 & 1,790 \\
\hline Other financial institutions & -535 & -542 & $-1,022$ & $-1,212$ & $-1,361$ & $-1,195$ \\
\hline Claims on nongovernment & 9,593 & 10,293 & 12,368 & 14,008 & 17,907 & 20,776 \\
\hline Claims on parastatals & 372 & 262 & 261 & 168 & 102 & 89 \\
\hline Claims on the private sector & 9,221 & 10,030 & 12,108 & 15,220 & 19,268 & 21,972 \\
\hline Other items (net) & $-5,108$ & $-9,946$ & $-14,367$ & $-14,707$ & $-22,071$ & $-20,177$ \\
\hline Capital & $-1,976$ & $-2,197$ & $-2,716$ & $-3,367$ & $-4,201$ & $-4,280$ \\
\hline Bank of Botswana & -54 & -59 & -65 & -67 & -75 & -66 \\
\hline Commercial banks & $-1,922$ & $-2,137$ & $-2,651$ & $-3,300$ & $-4,126$ & $-4,214$ \\
\hline Reserves & $-1,600$ & $-1,600$ & $-1,600$ & $-1,600$ & $-1,600$ & $-1,600$ \\
\hline Bank of Botswana & $-1,600$ & $-1,600$ & $-1,600$ & $-1,600$ & $-1,600$ & $-1,600$ \\
\hline Commercial banks & 0 & 0 & 0 & 0 & 0 & 0 \\
\hline Valuation adjustment 2/ & $-1,401$ & $-5,543$ & $-8,692$ & $-9,503$ & $-14,004$ & $-14,227$ \\
\hline Net unclassified assets & -131 & -606 & $-1,359$ & -237 & $-2,266$ & -70 \\
\hline Money plus quasi-money (M2) & 13,262 & 14,674 & 24,568 & 32,226 & 39,039 & 44,842 \\
\hline Money & 4,225 & 3,998 & 5,157 & 6,167 & 7,580 & 8,582 \\
\hline Currency & 632 & 625 & 753 & 908 & 1,103 & 1,263 \\
\hline Current deposits & 3,592 & 3,372 & 4,404 & 5,260 & 6,477 & 7,319 \\
\hline Quasi money & 9,037 & 10,676 & 19,411 & 26,058 & 31,459 & 36,260 \\
\hline Other monetary liabilities $3 /$ & 6,447 & 7,873 & 0 & 0 & 0 & 0 \\
\hline \multirow[t]{2}{*}{ Broad money (M3) } & 19,708 & 22,547 & 24,568 & 32,226 & 39,039 & 44,842 \\
\hline & \multicolumn{6}{|c|}{ (12-month percentage change) } \\
\hline Net foreign assets & 1.3 & 42.1 & 36.0 & 24.1 & 20.2 & 0.6 \\
\hline Bank of Botswana & 2.1 & 43.2 & 38.8 & 22.4 & 17.2 & 1.8 \\
\hline Commercial banks & -12.0 & 20.8 & -28.6 & 99.3 & 102.8 & -16.9 \\
\hline Net domestic assets & -22.3 & 140.2 & 81.5 & 17.0 & 19.1 & -15.8 \\
\hline Net domestic credit & -82.8 & 654.1 & 189.6 & 38.3 & -14.2 & -29.5 \\
\hline Net claims on the government & -3.2 & 36.4 & 62.3 & 25.1 & 6.8 & -2.0 \\
\hline of which: Bank of Botswana & -11.7 & 38.6 & 60.6 & 31.2 & 14.0 & -2.7 \\
\hline Claims on nongovernment & 23.9 & 7.3 & 20.2 & 13.3 & 27.8 & 16.0 \\
\hline Claims on parastatals & 18.1 & -29.4 & -0.6 & -35.4 & -39.6 & -12.2 \\
\hline Claims on the private sector & 24.1 & 8.8 & 20.7 & 25.7 & 26.6 & 14.0 \\
\hline Other items (net) & 13.0 & 94.7 & 44.5 & 2.4 & 50.1 & -8.6 \\
\hline Money plus quasi-money (M2) & 13.9 & 10.6 & 67.4 & 31.2 & 21.1 & 14.9 \\
\hline Broad money (M3) & 10.7 & 14.4 & 9.0 & 31.2 & 21.1 & 14.9 \\
\hline \multicolumn{7}{|l|}{ Memorandum items: } \\
\hline Nominal GDP (calendar year) & 47,155 & 52,449 & 65,692 & 75,728 & 91,213 & 80,087 \\
\hline Nominal non-mineral GDP (calendar year) & 29,663 & 32,513 & 37,781 & 45,163 & 53,646 & 59,826 \\
\hline Velocity (GDP relative to broad money, M2) & 3.6 & 3.6 & 2.7 & 2.3 & 2.3 & 1.8 \\
\hline Velocity (non-mineral GDP relative to broad money, M2) & 2.2 & 2.2 & 1.5 & 1.4 & 1.4 & 1.3 \\
\hline Private sector credit to GDP & 19.6 & 19.1 & 18.4 & 20.1 & 21.1 & 27.4 \\
\hline Private sector credit to non-mineral GDP & 31.1 & 30.9 & 32.0 & 33.7 & 35.9 & 36.7 \\
\hline
\end{tabular}

Sources: Bank of Botswana; and IMF staff estimates and projections.

1/ This table represents a depository corporations survey and the data are for end of period.

2/ Valuation adjustment reflects gains and losses arising from the valuation of foreign exchange reserves.

3/ Other monetary liabilities includes nonbank holdings of BoBCs; BoBCs cannot be held by nonbank financial institutions since March 2006. 
Table 6. Banking System Prudential Indicators, 2004-2009 1/

\begin{tabular}{|c|c|c|c|c|c|c|c|c|c|}
\hline & \multirow[t]{2}{*}{2004} & \multirow[t]{2}{*}{2005} & \multirow[t]{2}{*}{2006} & \multirow[t]{2}{*}{2007} & \multicolumn{4}{|c|}{2008} & \multirow{2}{*}{$\begin{array}{c}2009 \\
\text { Mar. }\end{array}$} \\
\hline & & & & & Mar. & Jun. & Sep. & $\overline{\mathrm{Dec}}$ & \\
\hline & \multicolumn{9}{|c|}{ (Percent, unless otherwise indicated) } \\
\hline \multicolumn{10}{|l|}{ Capital adequacy } \\
\hline Regulatory capital (millions of pula) 2/ & 1,404 & 1,569 & 1,743 & 2,295 & 2,526 & 2,670 & 2,926 & 2,992 & 3,340 \\
\hline Tier 1 capital (millions of pula) & 916 & 961 & 1,071 & 1,312 & 1,320 & 1,731 & 1,752 & 1,832 & 1,842 \\
\hline Risk Weighted Assets (in millions Pula) & 8,302 & 9,066 & 10,404 & 13,380 & 13,996 & 15,383 & 16,707 & 17,694 & 18,056 \\
\hline Total Assets (in millions Pula) & 14,842 & 17,761 & 29,256 & 37,139 & 40,930 & 41,684 & 45,190 & 45,318 & 41,688 \\
\hline Regulatory capital to risk-weighted assets $3 /$ & 16.9 & 17.3 & 16.8 & 17.2 & 18.0 & 17.4 & 17.5 & 16.9 & 18.5 \\
\hline Regulatory Tier I capital to risk-weighted assets 4/ & 11.0 & 10.6 & 10.3 & 9.8 & 9.4 & 11.3 & 10.5 & 10.4 & 10.2 \\
\hline Capital-to-assets & 9.5 & 8.8 & 6.0 & 6.2 & 6.2 & 6.4 & 6.5 & 6.6 & 8.0 \\
\hline \multicolumn{10}{|l|}{ Asset composition and quality } \\
\hline Loans-to-assets & 57.0 & 51.2 & 36.9 & 37.6 & 35.5 & 36.6 & 38.2 & 39.6 & 44.5 \\
\hline Nonperforming loans (NPLs)-to-gross loans 5/ & 0.8 & 0.9 & 0.9 & 2.0 & 2.5 & 2.3 & 2.2 & 1.6 & 2.9 \\
\hline Compromised assets-to-gross loans 5 / & 2.7 & 2.6 & 3.7 & 1.4 & 1.2 & 1.2 & 1.0 & 0.9 & 1.2 \\
\hline NPLs net of specific provisions-to-gross loans $5 /$ & 0.0 & 0.0 & 0.0 & 0.2 & 0.8 & 0.3 & 0.4 & -0.3 & 0.5 \\
\hline NPLs net of specific provisions-to-tier I capital 5/ & 0.0 & 0.0 & 0.0 & 2.2 & 8.8 & 2.6 & 3.9 & -2.5 & 4.7 \\
\hline \multicolumn{10}{|l|}{ Profitability } \\
\hline Return on average assets $6 /$ & 5.0 & 5.5 & 6.1 & 2.6 & 0.7 & 1.6 & 2.3 & 2.9 & 0.7 \\
\hline Return on average equity $6 /$ & 50.7 & 62.5 & 89.2 & 43.2 & 10.8 & 24.9 & 35.4 & 45.4 & 9.6 \\
\hline Net interest Margin to gross income & 38.0 & 38.2 & 31.8 & 65.4 & 65.8 & 63.6 & 64.5 & 65.2 & 67.5 \\
\hline Non-interest income to gross income & 22.2 & 23.2 & 17.8 & 34.6 & 34.2 & 36.4 & 35.5 & 34.8 & 32.5 \\
\hline Non-interest expenses to gross income & 28.9 & 27.1 & 20.2 & 45.2 & 41.6 & 43.9 & 43.8 & 45.5 & 45.1 \\
\hline \multicolumn{10}{|l|}{ Liquidity } \\
\hline $\begin{array}{l}\text { Liquid assets to total assets } \\
\text { of which: }\end{array}$ & 21.8 & 26.1 & 47.1 & 47.2 & 44.6 & 60.6 & 58.4 & 50.5 & 38.4 \\
\hline BoBCs to Total Assets & 15.9 & 19.6 & 43.4 & 44.9 & 40.1 & 40.5 & 39.6 & 38.7 & 36.6 \\
\hline Liquid assets to short-term liabilities & 27.4 & 35.5 & 60.5 & 53.7 & 52.1 & 68.9 & 66.6 & 56.9 & 44.6 \\
\hline Foreign currency denominated loans to total loans & 11.0 & 7.7 & 12.1 & 8.4 & 6.5 & 6.6 & 9.5 & 9.3 & 8.5 \\
\hline Foreign currency deposits to total deposits & 15.4 & 17.9 & 24.8 & 29.9 & 34.7 & 33.5 & 32.2 & 26.9 & 16.5 \\
\hline Foreign currency denominated liabilities to total liabilities & 18.4 & 22.5 & 29.1 & 45.7 & 60.6 & 68.1 & 63.2 & 53.5 & 50.6 \\
\hline Deposits-to-assets & 80.0 & 74.5 & 79.0 & 84.5 & 81.7 & 83.7 & 84.9 & 85.2 & 83.6 \\
\hline Loans-to-deposits & 71.2 & 68.7 & 46.7 & 44.5 & 43.4 & 43.8 & 45.0 & 46.5 & 53.2 \\
\hline \multicolumn{10}{|l|}{ Sensitivity to market risk } \\
\hline Net open foreign exchange (FX) position as percent of regulatory capital $7 /$ & -19.3 & 8.3 & -18.1 & 18.5 & 60.2 & 14.9 & 35.3 & 28.7 & 14.9 \\
\hline Contingent foreign exchange (FX) assets-to-regulatory capital & 23.6 & 70.7 & 258.2 & 242.6 & 294.6 & 247.8 & 232.4 & 132.7 & 76.5 \\
\hline Contingent foreign exchange (FX) liabilities-to-regulatory capital & 44.7 & 52.4 & 88.4 & 111.8 & 164.1 & 180.3 & 180.7 & 60.9 & 70.8 \\
\hline
\end{tabular}

Source: Bank of Botswana and FSAP estimates.

1/ The compilation methodology has changed somewhat since 2006; the number of banks has increased since 2007.

2/ Regulatory capital refers to the total of tier 1 and tier 2 capital, less investments in subsidiaries and associates.

$3 /$ The minimum capital requirement is 15 percent of risk weighted assets.

4/ The minimum capital requirement is 7.5 percent of risk weighted assets.

5/ NPLs are defined as credits with interest past due of 182 days or more; compromised assets are defined as credits with interest past due of 91 days or more. 6/ Quarterly figures for return on assets and return on equity in 2008 and 2009 are cumulative rather than annualized figures.

7/ Foreign currency liabilities less foreign currency assets as a percent of regulatory capital. 
Table 7. Millennium Development Goals

\begin{tabular}{|c|c|c|c|c|c|}
\hline & 1990 & 1995 & 2000 & 2007 & $\begin{array}{c}2007 \\
\text { SSA 1/ }\end{array}$ \\
\hline \multicolumn{6}{|l|}{ Goal 1: Eradicate extreme poverty and hunger } \\
\hline Income share held by lowest 20 percent & $\ldots$ & 3.1 & $\ldots$ & $\ldots$ & $\ldots$ \\
\hline Malnutrition prevalence, weight for age (percent of children under 5) & $\ldots$ & 17.2 & 12.5 & 10.7 & 26.6 \\
\hline Poverty gap at $\$ 1.25$ a day (PPP) (percent of population) & $\ldots$ & 11 & $\ldots$ & $\ldots$ & 51 \\
\hline Poverty headcount ratio at $\$ 1.25$ a day (PPP) (percent of population) & $\ldots$ & 31 & $\ldots$ & $\ldots$ & 29 \\
\hline Poverty headcount ratio at national poverty line (percent of population) $2 /$ & $\ldots$ & $\ldots$ & $\ldots$ & $\ldots$ & $\ldots$ \\
\hline Prevalence of undernourishment (percent of population) & 20 & 24 & $\ldots$ & 26 & $\cdots$ \\
\hline \multicolumn{6}{|l|}{ Goal 2: Achieve universal primary education } \\
\hline Literacy rate, youth total (percent of people ages 15-24) & 89 & $\ldots$ & $\ldots$ & 94 & 72 \\
\hline Persistence to grade 5, total (percent of cohort) & 77 & $\ldots$ & 85 & $\ldots$ & $\ldots$ \\
\hline Primary completion rate, total (percent of relevant age group) & 89 & 91 & 90 & 95 & 60 \\
\hline School enrollment, primary (percent net) $3 /$ & $\ldots$ & $\ldots$ & 83 & 84 & 71 \\
\hline \multicolumn{6}{|l|}{ Goal 3: Promote gender equality and empower women } \\
\hline Proportion of seats held by women in national parliament (percent) & 5 & 9 & 17 & 11 & 17 \\
\hline Ratio of girls to boys in primary and secondary education (percent) & $\ldots$ & $\ldots$ & 74 & 100 & 68 \\
\hline $\begin{array}{l}\text { Share of women employed in the nonagricultural sector } \\
\text { (percent of total nonagricultural employment) }\end{array}$ & 33.5 & 38.4 & 39.4 & 42.4 & $\cdots$ \\
\hline \multicolumn{6}{|l|}{ Goal 4: Reduce child mortality } \\
\hline Immunization, measles (percent of children ages $12-23$ months) & 87 & 89 & 90 & 90 & 73 \\
\hline Mortality rate, infant (per 1,000 live births) $3 /$ & 45 & 53 & 64 & 33 & 89 \\
\hline Mortality rate, under-5 (per 1,000$) 3 /$ & 57 & 70 & 87 & 40 & 146 \\
\hline \multicolumn{6}{|l|}{ Goal 5: Improve maternal health } \\
\hline Births attended by skilled health staff (percent of total) & 77 & 87 & 94 & $\ldots$ & 45 \\
\hline Maternal mortality ratio (modeled estimate, per 100,000 live births) & $\cdots$ & $\cdots$ & $\cdots$ & 380 & 900 \\
\hline \multicolumn{6}{|l|}{ Goal 6: Combat HIVIAIDS, malaria, and other diseases } \\
\hline Incidence of tuberculosis (per 100,000 people) & 307 & 444 & 640 & 731 & 369 \\
\hline Prevalence of HIV, female (percent ages 15-24) & $\ldots$ & $\ldots$ & $\ldots$ & 15.3 & 3.3 \\
\hline Prevalence of HIV, total (percent of population ages 15-49) 4/ & $\ldots$ & $\ldots$ & $\ldots$ & 17.6 & 5 \\
\hline Tuberculosis cases detected under DOTS (percent) $5 /$ & $\ldots$ & 70 & 73 & 57 & 49 \\
\hline \multicolumn{6}{|l|}{ Goal 7: Ensure environmental sustainability } \\
\hline CO2 emissions (metric tons per capita) & 1.6 & 2.2 & 2.5 & 2.5 & 0.8 \\
\hline Forest area (percent of land area) & 24 & 23 & 22 & 21 & 26 \\
\hline Improved sanitation facilities (percent of population with access) & 38 & 42 & 45 & 47 & 31 \\
\hline Improved water source (percent of population with access) & 93 & 94 & 95 & 96 & 58 \\
\hline Nationally protected areas (percent of total land area) & $\cdots$ & $\cdots$ & $\cdots$ & 308 & 11.3 \\
\hline \multicolumn{6}{|l|}{ Goal 8: Develop a global partnership for development } \\
\hline Aid per capita (current US\$) & 106 & 57 & 18 & 56 & 44 \\
\hline $\begin{array}{l}\text { Debt service (PPG and IMF only, } \\
\text { percent of exports, excl. workers' remittances) }\end{array}$ & 4 & 3 & 2 & 1 & 4 \\
\hline Telephone lines (per 100 people) & 2 & 4 & 8 & 7 & 2 \\
\hline Mobile cellular subscriptions (per 100 people) & 0 & 0 & 13 & 61 & 23 \\
\hline Internet users (per 100 people) & 0 & 0.1 & 2.9 & 5.3 & 4.4 \\
\hline \multicolumn{6}{|l|}{ Other } \\
\hline Fertility rate, total (births per woman) & 4.6 & 3.9 & 3.4 & 2.9 & 5.1 \\
\hline GNI per capita, Atlas method (current US\$) & 2,560 & 3,040 & 3,310 & 6,120 & 951 \\
\hline GNI, Atlas method (current US\$ billions) & 3.5 & 4.8 & 5.7 & 11.5 & 761 \\
\hline Gross capital formation (percent of GDP) & 37.4 & 24.6 & 35.0 & 40.7 & 21.9 \\
\hline Life expectancy at birth, total (years) 3/ & 63 & 57 & 49 & 51 & 51 \\
\hline Literacy rate, adult total (percent of people ages 15 and above) & 69 & $\ldots$ & $\ldots$ & 83 & 62 \\
\hline Population, total (millions) & 1.4 & 1.6 & 1.7 & 1.9 & 800 \\
\hline Trade (percent of GDP) & 104.8 & 89 & 86.2 & 83.7 & 71.3 \\
\hline
\end{tabular}

Source: World Bank, World Development Indicators, 2009.

Note: Figures in italics refer to periods other than those specified.

1 / SSA represents the average for the sub-Saharan Africa region.

2/ Poverty headcount ratio at national poverty line updated from the Botswana 2002-2003 HIES.

3/ Data taken from the Botswana Millennium Development Goals, Status Report, 2004.

4/ Data taken from the National AIDS Coordinating Agency, BAIS II, 2004 and are for the entire population aged 18 months and above.

5/ The Directly Observed Treatment, Short-course (DOTS) is a WHO-recommended strategy for detection and cure of TB. 
Table 8. Competitiveness Rankings

\begin{tabular}{|c|c|c|c|c|}
\hline & 2005 & 2006 & 2007 & 2008 \\
\hline \multicolumn{5}{|c|}{ Global Competitiveness Index Ranking * } \\
\hline Argentina & 54 & 69 & 85 & 88 \\
\hline Botswana & 72 & 81 & 55 & 56 \\
\hline Chile & 27 & 27 & 28 & 28 \\
\hline Colombia & 58 & 65 & 73 & 74 \\
\hline Lesotho & & 112 & 119 & 123 \\
\hline Malaysia & 25 & 26 & 21 & 21 \\
\hline Mauritius & 55 & 55 & 56 & 57 \\
\hline Namibia & 79 & 84 & 79 & 80 \\
\hline South Africa & 40 & 45 & 44 & 45 \\
\hline Swaziland & $\cdots$ & $\cdots$ & $\ldots$ & $\ldots$ \\
\hline No. of Countries & 117 & 125 & 130 & 134 \\
\hline \multicolumn{5}{|c|}{ Ease of Doing Business Ranking * } \\
\hline Argentina & 93 & 101 & 102 & 113 \\
\hline Botswana & 44 & 48 & 52 & 38 \\
\hline Chile & 24 & 28 & 36 & 40 \\
\hline Colombia & 76 & 79 & 66 & 53 \\
\hline Lesotho & 116 & 114 & 119 & 123 \\
\hline Malaysia & 25 & 25 & 25 & 20 \\
\hline Mauritius & 32 & 32 & 29 & 24 \\
\hline Namibia & 39 & 42 & 48 & 51 \\
\hline South Africa & 28 & 29 & 35 & 32 \\
\hline Swaziland & 67 & 76 & 100 & 108 \\
\hline No. of Countries & 175 & 175 & 181 & 181 \\
\hline
\end{tabular}

Sources: World Economic Forum, Global Competitiveness Report 2008-09, and World Bank, Doing Business Indicators 2009. 


\section{INTERNATIONAL MONETARY FUND}

BOTSWANA

\section{Staff Report for the 2009 Article IV Consultation-Informational Annex}

Prepared by the African Department

(In consultation with other departments)

Approved by Saul Lizondo and Dhaneshwar Ghura

July 2, 2009

- $\quad$ Relations with the Fund: The last Article IV consultation was concluded in December 2007.

- JMAP.

- Statistical Issues: Botswana subscribes to the General Data Dissemination System (GDDS).

- Debt Sustainability Analysis 


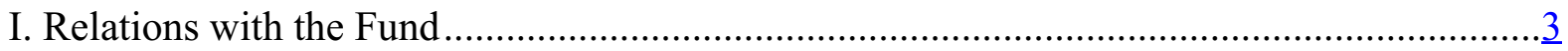

II. JMAP: Botswana-World Bank and IMF Work Programs ….........................................

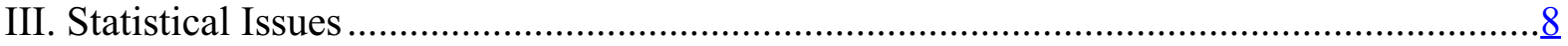

IV. Public Sector Debt Sustainability Analysis ............................................................12

V. External Debt Sustainability Analysis ..................................................................

Table

1. Common Indicators Required for Surveillance ..........................................................11 


\section{RELATIONS WITH THE FUND}

(As of April 30, 2009)

I. Membership status Joined July 24, 1968; VIII.

II. General resources account

Quota

Fund holdings of currency

Reserve position in Fund

III. SDR department

Net cumulative allocation

Holdings

\begin{tabular}{r} 
SDR (million) \\
63.00 \\
54.53 \\
8.48 \\
\\
SDR (million) \\
\hline 4.36 \\
39.66
\end{tabular}

39.66
Percent of Quota

100.00

86.56

13.45

Percent of Quota

100.00

909.81

IV. Outstanding purchases and loans

None

V. Financial arrangements

None

VI. Project obligations to Fund

None

VII. Implementation of HIPC initiative

None

\section{Exchange rate arrangements}

The exchange rate of the Botswana pula is a crawling peg arrangement against a basket of currencies. As of May 31, 2009, the exchange rate of the U.S. dollar to the pula was $\mathrm{US} \$ 1=\mathrm{P} 6.88$, and that of the South African rand to the pula was $\mathrm{R} 1=\mathrm{P} 0.84$.

Botswana accepted the obligations of Article VIII, Sections 2, 3, and 4 of the Fund's Articles of Agreement, as of November 17, 1995, and maintains an exchange rate system free of restrictions in the making of transfers and payments of current account transactions.

\section{Article IV consultation}

Botswana is on a standard 12-month consultation cycle. The last Article IV consultation was concluded by the Executive Board on December 7, 2007. Directors agreed with the thrust of the staff appraisal.

\section{Technical assistance assignments/projects}

Department

MFD

STA
Dates

1997

1999-2000

1997
Position

Central banking advisor

Banking supervision advisor

Balance of payments advisor 


\section{Technical assistance missions}

\section{Department}

MFD

FAD

LEG

STA
Dates

January 2001

February 2001

December 2001

August 2002

July 2004

August 2004

November 1997

September 2000

February 2002

November 2004

January 2006

July 2006

June 2007

May 2001

April 2002

July 2002

August 2003

June 2004

August 2004

October 2004

June 2005

August 2005

March 2006

March 2006

October 2006

October 2007

November 2007-

November 2008

November 2008

\section{Purpose}

Banking supervision advisor

Monetary operations

MEFMI-Monetary operations

Banking supervision, anti-money laundering

NBFI supervision

Money and banking statistics follow-up

Introduction of a VAT

Implementation of VAT next steps

Tax administration (SADC Region)

Public expenditure management

Review of amended VAT provisions

Review of central bank law

Review of VAT laws

Inspection for visit of long-term

balance of payments advisor

ROSC data module

BOP statistics: peripatetic visit

Monetary and financial statistics using

the GDDS

GDDS project for Anglophone Africa:

National accounts statistics

Follow-up mission: Money and banking statistics

GDDS: National accounts mission

Follow-up on monetary and financial statistics using the GDDS

Follow-up mission: GDDS quarterly balance of payments statistics

GDDS project for Anglophone Africa:

balance of payments statistics

GDDS project for Anglophone Africa:

national accounts statistics

ROSC data module covering GDDS and Data

Quality Assessment Framework (DQAF)

Monetary and Financial Statistics

Real Sector Statistics (Resident Regional Advisor)

Money and Banking Statistics 
February 2009

June 2009-

June 2010

MCM

January, March

2007

December 2008

January 2009

February 2009,

April 2010

July 2009
Phase II SDDS- Balance of Payments Statistics Real Sector Statistics (Resident Regional Advisor)

IMF-World Bank Financial Sector Assessment Program (FSAP)

Inflation forecasting and modeling

Risk Management Framework

Payments Systems (LT Resident Expert

Assignment)

Monetary Operations 


\section{JMAP: BOTSWANA-WORLD BANK AND IMF WORK PROGRAMS}

(As of June 9, 2009)

\begin{tabular}{|c|c|c|c|}
\hline Title & Products & $\begin{array}{l}\text { Provisional Timing } \\
\text { of Missions }\end{array}$ & Expected Delivery Date \\
\hline \multicolumn{4}{|c|}{ A. Mutual Information on Relevant Work Programs } \\
\hline \multirow{17}{*}{$\begin{array}{l}\text { World Bank indicative } \\
\text { work program in the } \\
\text { next } 12 \text { months }\end{array}$} & 1. Country Partnership Strategy & & $\begin{array}{l}\text { Bank Board Q4, FY09 } \\
\text { (discussed) }\end{array}$ \\
\hline & 2. Electricity Program & & \\
\hline & $\begin{array}{l}\text { Morupule B Generation and } \\
\text { Transmission Power Project } \\
\text { (SIL/PCG) }\end{array}$ & & FY10 \\
\hline & $\begin{array}{l}\text { - Mmamabula IPP Power Project } \\
\text { PRG (TBD) }\end{array}$ & & FY11 (TBD) \\
\hline & 3. HIV/AIDS Project & & $\begin{array}{l}\text { Bank Board Q1, FY09 } \\
\text { (approved) }\end{array}$ \\
\hline & 4. Integrated Transport Project & & $\begin{array}{l}\text { Bank Board Q4, FY09 } \\
\text { (approved) }\end{array}$ \\
\hline & 5. DPL (Budget Support) & & FY10 \\
\hline & $\begin{array}{l}\text { Wildlife Conflict Management } \\
\text { and Biodiversity Conservation } \\
\text { for Improved Rural Livelihoods } \\
\text { Project (Global Environment } \\
\text { Facility) }\end{array}$ & & Q2, FY10 \\
\hline & $\begin{array}{l}\text { 7. Statistics/Capacity-building } \\
\text { - Strengthening Monitoring and } \\
\text { Evaluation capacity for Vision } \\
\text { 2016 Council (IDF Grant) }\end{array}$ & & FY10; On-going \\
\hline & $\begin{array}{l}\text { - Strengthening Institute \& } \\
\text { Accountants (IDF Grant) }\end{array}$ & & FY10; On-going \\
\hline & $\begin{array}{l}\text { - Strengthening Statistical Capacity } \\
\text { for Poverty Analysis }\end{array}$ & & FY09 \\
\hline & $\begin{array}{l}\text { 8. Carbon Finance Assistance } \\
\text { Program }\end{array}$ & & FY10 \\
\hline & $\begin{array}{l}\text { 9. Post ICA Follow-up/Financial } \\
\text { Systems Stability Assessment (TA) }\end{array}$ & & FY10 \\
\hline & 10. Water Sector: & & FY09/FY10 \\
\hline & $\begin{array}{l}\text { - FBSA Technical Advisory Services } \\
\text { (Phases } 1 \text { \& 2) }\end{array}$ & & FY10 \\
\hline & $\begin{array}{l}\text { 11. Sustainable Development (SDN) } \\
\text { Policy Notes }\end{array}$ & & FY10 \\
\hline & 12. PER/PFM Reform (TA) & & FY11 \\
\hline
\end{tabular}




\begin{tabular}{|c|c|c|c|}
\hline Title & Products & $\begin{array}{l}\text { Provisional Timing } \\
\text { of Missions }\end{array}$ & Expected Delivery Date \\
\hline & \multicolumn{2}{|l|}{ 13. Development Policy Review (DPR) } & FY10 \\
\hline & \multicolumn{2}{|l|}{ 14. Skills Gap/Labor Markets } & FY10 \\
\hline & \multicolumn{2}{|l|}{ 15. Macro-Modeling (TA) } & FY10 \\
\hline & \multicolumn{2}{|l|}{ 16. Capacity building in NBFI (TA) } & FY10 \\
\hline & \multicolumn{2}{|l|}{$\begin{array}{l}\text { 17. Strategic Issues in Competitiveness } \\
\text { Study }\end{array}$} & FY10 \\
\hline & \multicolumn{2}{|l|}{$\begin{array}{l}\text { 18. Issues Notes on Accrual } \\
\text { Accounting }\end{array}$} & FY10 \\
\hline \multirow[t]{5}{*}{$\begin{array}{l}\text { IMF work program in } \\
\text { the next } 12 \text { months }\end{array}$} & $\begin{array}{l}\text { STA TA on monetary and balance of } \\
\text { payments statistics }\end{array}$ & \multicolumn{2}{|l|}{ Ongoing } \\
\hline & $\begin{array}{l}\text { MCM TA on monetary and financial } \\
\text { sector issues, including: revision of the } \\
\text { Bank of Botswana Act and the Banking } \\
\text { Act; macroeconomic modeling; } \\
\text { payment systems modernization }\end{array}$ & \multicolumn{2}{|l|}{ Ongoing FY 2010} \\
\hline & $\begin{array}{l}\text { FAD TA on tax administration and } \\
\text { public financial management }\end{array}$ & \multicolumn{2}{|l|}{ Expected FY 2010} \\
\hline & $\begin{array}{l}\text { LEG TA on tax administration and } \\
\text { income tax law reform }\end{array}$ & \multicolumn{2}{|l|}{ Expected FY 2010} \\
\hline & Article IV consultation & \multicolumn{2}{|l|}{ May 2009} \\
\hline \multicolumn{4}{|c|}{ B. Requests for Work Program Inputs } \\
\hline Fund request to Bank & Periodic update on progress & & \\
\hline Bank request to Fund & Periodic macro update & & \\
\hline
\end{tabular}




\section{Statistical IsSues}

1. Data provision is adequate to conduct surveillance, but there are some shortcomings. The accuracy of data, particularly for the national accounts and balance of payments, needs improvement. National accounts are now prepared on a calendar basis rather than the JulyJune schedule. Historical data have been adjusted accordingly

2. A ROSC reassessment took place October 31-November 13, 2006 and the report, along with the authorities' response, was published on April 6, 2007. Cross-cutting recommendations were to monitor the consistency of the main macroeconomic datasets and reconcile differences regularly; establish a list of institutional units consistent with sectorization in the 1993 System of National Accounts (1993 SNA), to be applied consistently across all datasets; and support greater use of preliminary data by formalizing revision policies and implementing regular revision cycles.

3. As one of 22 countries participating in the Fund's General Data Dissemination System (GDDS) Project for Anglophone African Countries, Botswana has undertaken to use the GDDS as framework for the development of its national statistical system. Also, in preparation for eventual SDDS subscription, Botswana is participating in the monetary and financial statistics modules of the Anglophone Africa project (funded by the U.K. Department for International Development (DFID)). This project aims to assist participating countries to implement plans for improvement identified in the metadata, which were posted on the Fund's Dissemination Standards Bulletin Board on October 24, 2002. Recent advances include the publication of the National Summary Data Page on the BoB website and the dissemination of advance release calendars for key macroeconomic data.

\section{National accounts and prices}

4. Using the production and expenditure approaches, national accounts are now principally based on the concepts and definitions recommended by the 1993 SNA, in line with the strong commitment of the authorities to migrate to the 1993 SNA, but some changes are needed for full observance. For instance, classification and sector breakdowns are still broadly in line with 1968 SNA. Staff welcomes the authorities recent decision to harmonize the accounting period for national accounts It would be important to conduct comprehensive enterprise surveys every few years and introduce estimates for the informal sector. Detailed recommendations are contained in the April 2007 ROSC report.

5. The consumer price index is comprehensive and provides breakdowns between urban and rural areas and between tradable (domestic and imported) and nontradables. The Classification of Individual Consumption by Purpose (COICOP) in the rebased CPI (September 2006) broadly conforms with the guidelines of 1993 SNA and the CPI Manual, although there are still deviations with respect to the imputation of rents and owner-occupied housing. Estimates from the Household Income and Expenditure Survey (HIES) are used for the weights of market expenditure for goods and services. With respect to the wholesale price index (WPI), the ROSC mission recommended the development of concepts and definitions to meet the needs of data users. The Central Statistics Office is to decide whether to produce 
an output index (PPI), an Intermediate Consumption Index or a Supply Price Index. Currently, the WPI of industrial output is not representative of industrial production, because it measures changes in the prices of only six product groups.

\section{Fiscal accounts}

6. The concepts and definitions used in compiling central government finance statistics generally follow the methodology of the IMF's Government Finance Statistics Manual (GFSM 1986) but cover only budgetary central government activities. No fiscal statistics are compiled for extrabudgetary institutions and consolidated central government. The classification used for budgetary central government partially follows the concepts of GFSM 1986. Detail on some components of current spending is lacking. Transactions are recorded on a cash basis consistent with the GFSM 1986 guidelines. In general, the statistics disseminated in official publications are presented clearly and are made available to all users simultaneously. The data ROSC mission recommended at least annual compilation and dissemination of GFS for extrabudgetary institutions, and the consolidated general government. The authorities have yet to decide on a suitable "migration path" to adopt the GFSM 2001 methodology. The authorities regularly report monthly data on budgetary central government for inclusion in the International Financial Statistics (IFS), but no data are reported for inclusion in the Government Finance Statistics Yearbook.

7. The periodicity of central government finance statistics meets GDDS standards, except for timeliness. It should be noted that information is available to permit compilation and dissemination of government finance statistics within the GDDS recommendations.

\section{Monetary accounts}

8. The Bank of Botswana's $(\mathrm{BoB})$ compilation of the depository corporations survey is generally consistent with the methodology recommended in the Fund's Monetary and Financial Statistics Manual (MFSM). The survey covers BoB and all other depository corporations, excluding Savings and Credit Cooperatives, that issue liabilities included in the national definition of broad money as recommended in the MFSM. Classification and sectorization are largely consistent with MFSM, except for the classification of financial derivatives. In addition, some nonbudgetary central government units are classified as nonfinancial public corporations and accrued interest is not consistently presented together with the underlying instrument.

9. Monetary data for publication in International Financial Statistics are reported regularly using Standardized Report Forms. Although reporting is more timely, data concerning the central bank are still being reported to STA with a longer lag than those for the other depository corporations.

\section{External sector statistics}

10. The concepts, structure and definitions of the balance of payments statistics follow the fifth edition of the Balance of Payments Statistics Manual (BPM5). Institutional classifications generally follow BPM5, although data sources raise minor issues, in 
particular, administrative sources using definitions and classifications that deviate from BPM5. Source data are adequate, but International Transaction Reporting System (ITRS) data, used mostly for services, have become unreliable, and alternative data sources are needed. Data compilation, estimation, and adjustments mostly employ sound techniques. However, the methods for estimating missing data and calculating flows from stock data are inadequate.

11. Balance of payments statistics are compiled and published in the BoB's monthly statistical bulletin and the Annual Report, thus meeting GDDS periodicity and timeliness recommendations, although only annual balance of payments statistics are reported to STA for publication. There are discrepancies with national accounts statistics concerning imports, exports, and payments related to settlements within the Southern African Customs Union (SACU), mainly due to different data sources and valuation methods. A recent TA mission has identified gaps in recording of portfolio investments and services. 


\section{Table 1. Botswana: Common Indicators Required for Surveillance}

(As of June 10, 2009)

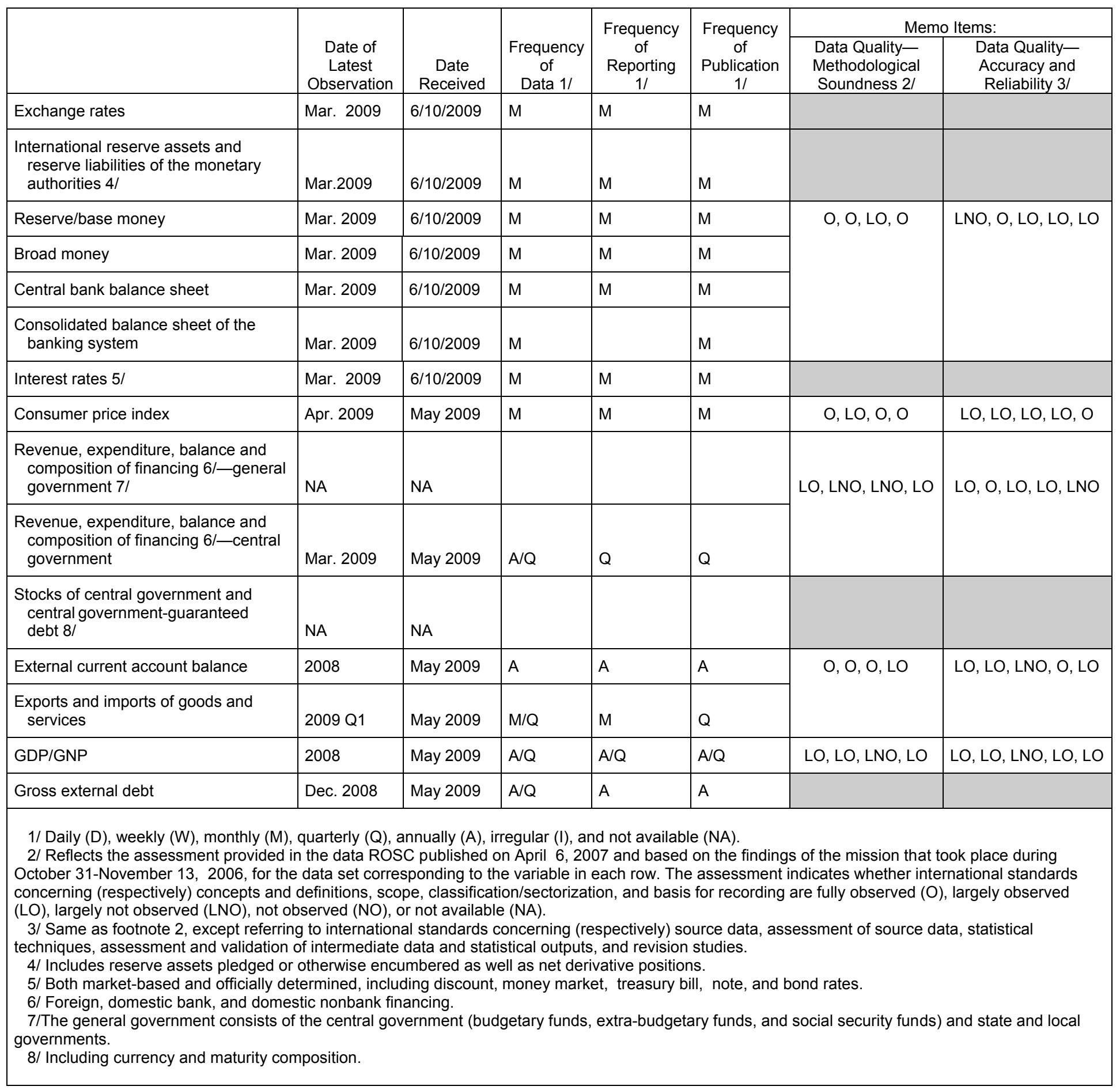




\section{Public Sector Debt Sustainability Analysis}

The public sector debt sustainability analysis (DSA) shows little risk of debt distress, even under various stress tests. Despite the sizeable increase in public debt expected during 200910, the DSA indicates that Botswana's public debt would remain sustainable over the medium term. However, continued large fiscal deficit over the medium term would worsen the debt indicators considerably, underscoring the need for fiscal measures.

1. At end-2008, Botswana's public debt is estimated at about P5.1 billion, (5.6 percent of GDP). About 30 percent of the debt is owed to bilateral and multilateral foreign creditors, while the rest is domestic debt. Botswana has a historically low level of public debt thanks to sound fiscal policies, which has led to fiscal surpluses and an accumulation of government reserves. However, the global financial crisis and the resulting lower demand for diamond has contributed to a sharp decline in government mineral revenues. This, combined with a significant rise in public spending, would result in a large fiscal deficit of 11.1 percent of GDP in FY 2009/10, which is expected to be more than fully financed by a budget support loan from the African Development Bank (AfDB), amounting to about 13 percent of GDP. On current projections, the debt-to-GDP ratio would rise from 5.6 percent of GDP in 2008 to 24.4 percent of GDP by 2010, driven largely by rising external debt and a decline in GDP by 10.3 percent in 2009, before declining thereafter to reach 15 percent of GDP by 2014.

2. The baseline scenario underlying the macroeconomic framework assumes that the central government primary budget balance moves from a substantial surplus in 2007 to a deficit in 2008, and remains so through 2011 before returning into a surplus during 20122014. Revenue and grants are projected to remain stable around 33 percent of GDP in the medium term, while primary expenditure is projected to increase by 8.5 percentage point of GDP in 2009, as the government undertakes large infrastructure projects. Expenditures would gradually decline in the medium term, as ongoing infrastructure projects are completed. Reflecting the more expansionary fiscal stance, the public debt-to-revenue ratio, which was 17.1 percent in 2008, would increase to 46.4 percent of GDP by 2014.

3. Table 1 presents two additional scenarios. The first scenario shows the fiscal outcome if real GDP growth, real interest rates, and the primary balance are maintained at their historical 10 year averages. In this case, the public debt-to-GDP ratio would drop to zero by 2012, reflecting strong economic growth, as well as the prudent fiscal stance in the recent past. The second scenario shows the outcome if the government's policies remain unchanged, with the result that the primary deficit for the projection period remains at the unprecedented level of 9.5 percent of GDP. In this case, debt indicators would worsen considerably, with public debt rising to 48.2 percent of GDP by the end of the forecast period, underscoring the need to reduce expenditures to sustainable levels.

4. The bounds tests illustrate the sensitivity of the fiscal position to exogenous shocks (Figure 1). The results show that with different levels of standard deviation shock to key 
indicators, the debt-to-GDP ratio is projected to increase by between 3 to 12 percentage points of GDP depending on the shock. The most benign shock is that from the real interest rate, which nevertheless could result in up to 3.4 percentage points increase in the debt-toGDP ratio relative to the baseline scenario, while a worsening in the 10 year historical average primary balance by one standard deviation results in a 11.7 percentage points increase in the debt-to-GDP ratio. 
Table 1. Botswana: Public Sector Debt Sustainability Framework, 2004-2014

(In percent of GDP, unless otherwise indicated)

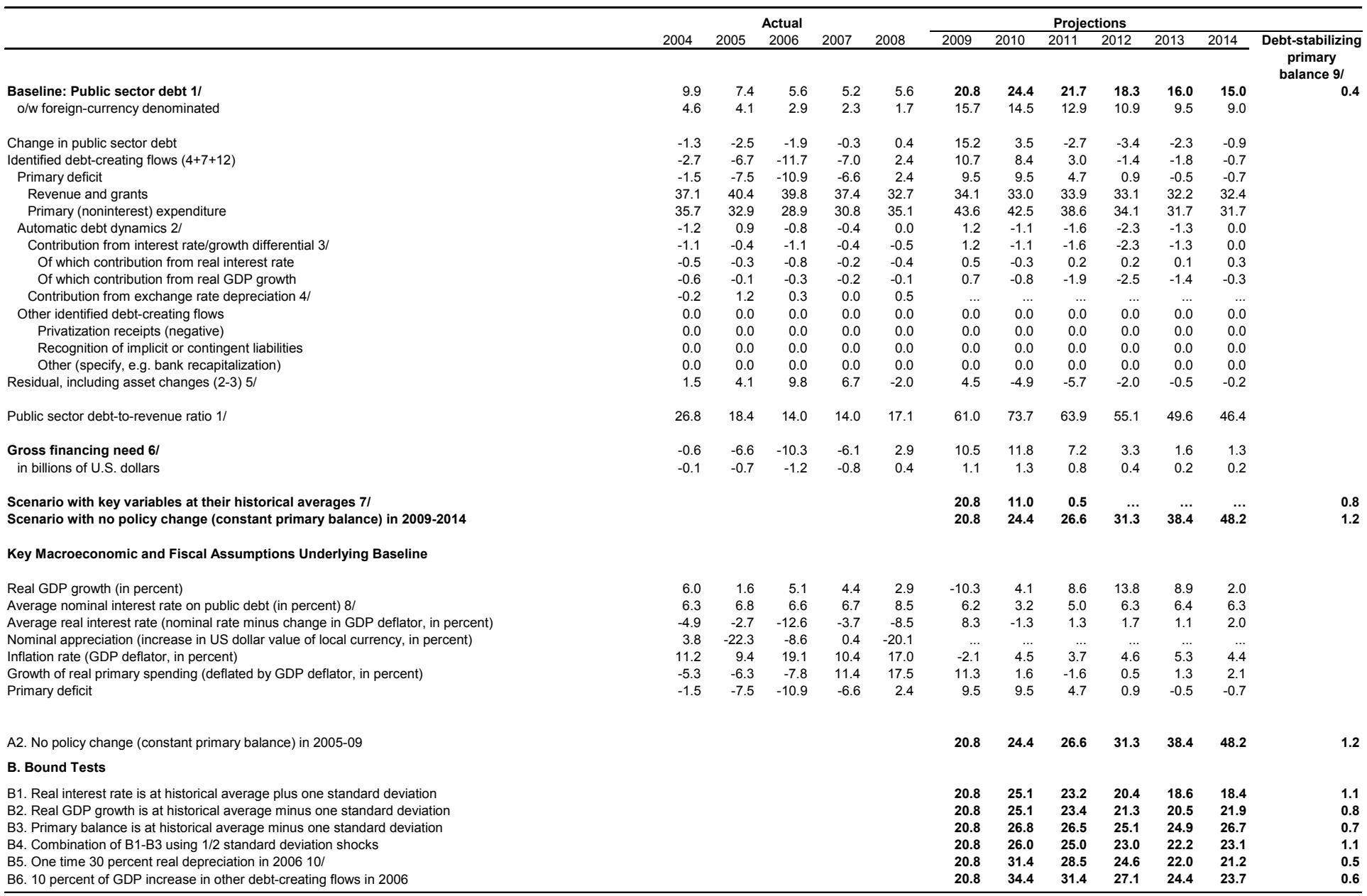

B6. 10 percent of GDP increase in other debt-creating flows in 2000

$1 /$ Indicate coverage of public sector, e.g., general government or nonfinancial public sector. Also whether net or gross debt is used.

/ Derived as $[(r-\pi(1+g)-g+\alpha s(1+r)](1+g+\pi+g))$ times previous period debt ratio, with $r=$ interest rate; $\pi=$ growth rate of $G D P$ deflator; $g=$ real GDP growth rate; $\alpha=$ share of foreign-currency

(1)

The real interest rate contribution is derived from the denominator in footnote $2 /$ as $r-\pi(1+g)$ and the real growth contribution as $-g$

$4 /$ The exchange rate contribution is derived from the numerator in footnote $2 /$ as $\alpha \varepsilon(1+r)$.

$5 /$ For projections, this line includes exchange rate changes.
$6 /$ Defined as public sector deficit, plus amortization of medium and long-term public sector debt, plus short-term debt at end of previous period.

Terived as nominal interest expentiture divided by previous period debt stock con

9/ Assumes that key variables (real GDP growth, real interest rate, and other identified debt-creating flows) remain at the level of the last projection year. 
Figure 1. Botswana: Public Debt Sustainability: Bound Tests 1/ (Public debt in percent of GDP)

Baseline and historical scenarios

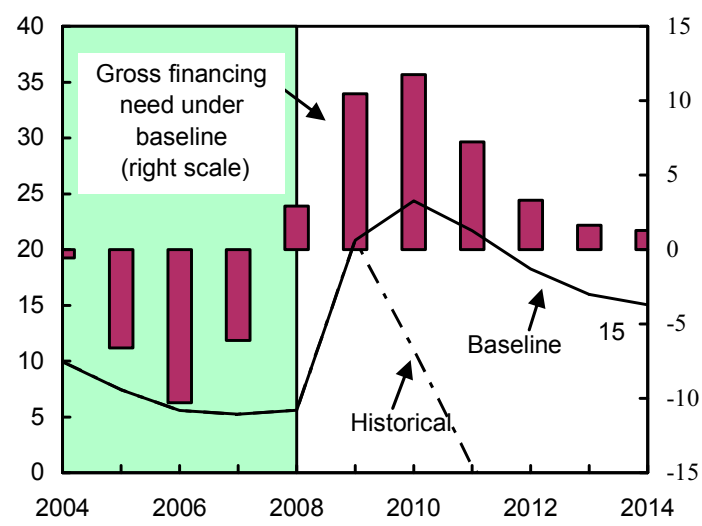

Growth shock (in percent per year)

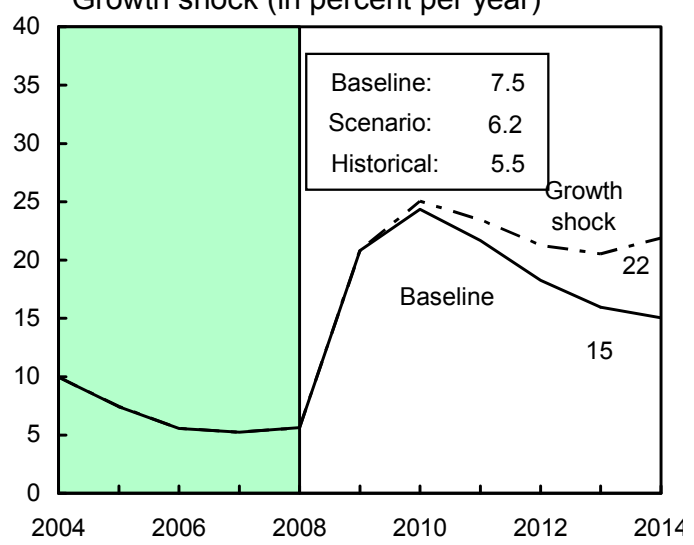

Combined shock 2/

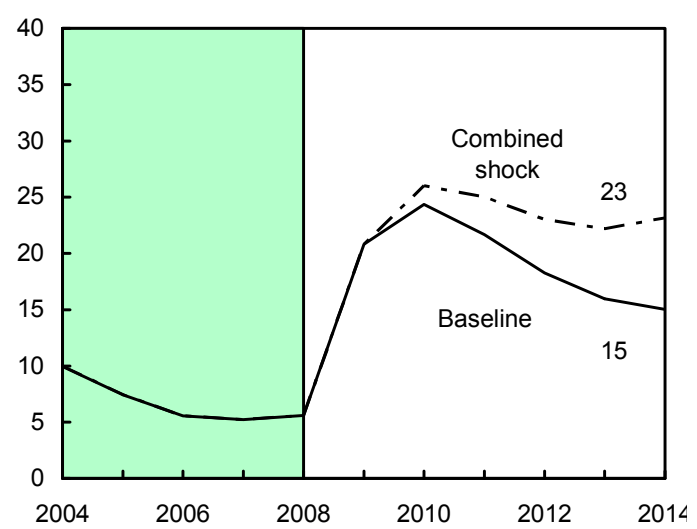

Interest rate shock (in percent)

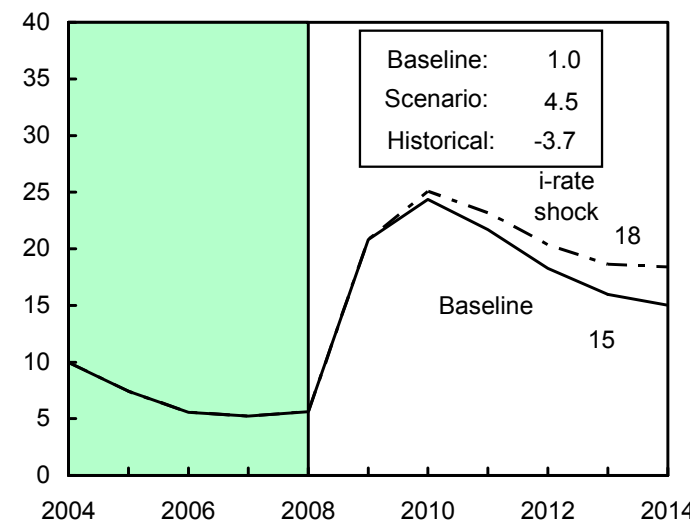

Primary balance shock (in percent of GDP) and no policy change scenario (constant primary balance)

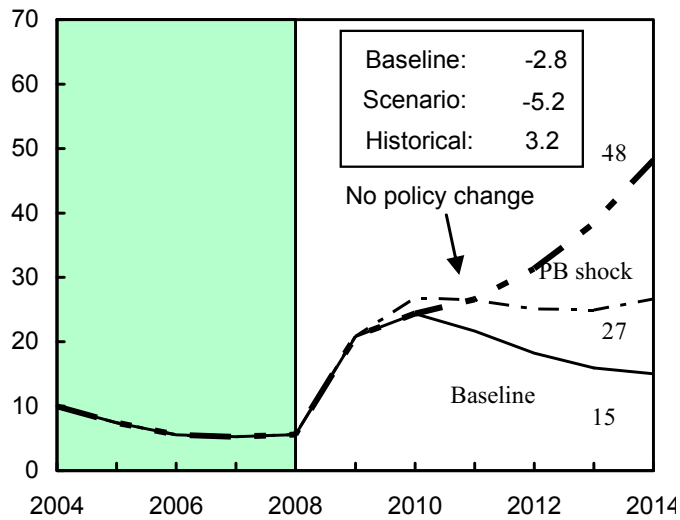

Real depreciation and contingent liabilities shocks 3/

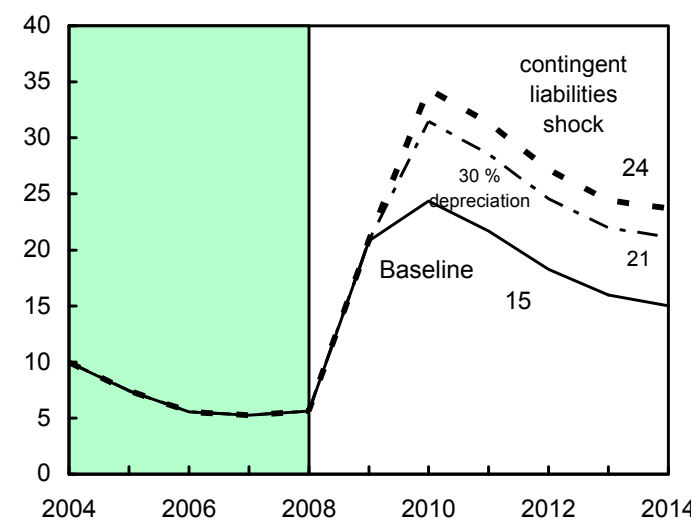

Sources: International Monetary Fund, country desk data, and staff estimates.

$1 /$ Shaded areas represent actual data. Individual shocks are permanent one-half standard deviation shocks. Figures in the boxes represent average projections for the respective variables in the baseline and scenario being presented. Ten-year historical average for the variable is also shown.

2/ Permanent $1 / 4$ standard deviation shocks applied to real interest rate, growth rate, and primary balance.

$3 /$ One-time real depreciation of 30 percent and 10 percent of GDP shock to contingent liabilities occur in 2009, with real depreciation defined as nominal depreciation (measured by percentage fall in dollar value of local currency) minus domestic inflation (based on GDP deflator). 


\section{EXternal DebT SustainabiLity ANaLysis}

The external debt sustainability analysis indicates that Botswana's external debt would remain sustainable in the medium term even under various stress tests. Total external debt is projected to increase substantially, although from a very low level at present, reflecting external budget support and financing of the power plant projects.

1. Botswana's gross external debt stood at $\$ 1.2$ billion (11.2 percent of GDP) at the end of 2008, with shortterm debt accounting for onefifth of total external debt. Public external debt was at a low level of 2.7 percent of GDP in 2008.

2. Under the baseline medium-term macroeconomic scenario, gross external debt is projected to increase to 48.1 percent of GDP by 2012, and trend downward thereafter to 40.8 percent of GDP by 2014 .

\begin{tabular}{|lr|}
\hline \multicolumn{2}{|c|}{ Table 1. External Debt Indicators, 2008 } \\
\hline \\
\hline \\
Gross external debt (in millions of U.S. dollars) & 2008 \\
(in percent of GDP) & 1,248 \\
Of which: & 11.2 \\
$\quad$ Public debt & 295 \\
$\quad$ (in percent of GDP) & 2.7 \\
Short-term debt (in millions of U.S.dollars) & 250 \\
$\quad$ (in percent of GDP) & 2.3 \\
Gross official reserves (in millions of U.S. dollars) & 9,125 \\
(ratio to short-term debt) & 36.5 \\
(ratio to reserve money) & 3.3 \\
& \\
Memorandum items: & \\
GDP at current market prices (in million U.S.dollars) & 11,101 \\
Reserve money (in million U.S. dollars) & 2,745 \\
& \\
&
\end{tabular}

This reflects primarily the new loan from the AfDB (US\$1.5 billion) and the external borrowing related to the Morupule (US\$750 million) and Mmamabula (US\$2.4 billion) power plant projects. The initial increase in 2009 is also explained by the projected 10.3 percent contraction in real GDP due to significantly lower diamond production. The current account surplus, excluding interest payments, is expected to turn into a deficit during 200911 , largely owing to a drop in external demand for diamonds in 2009 and a rise in imports related to the power plant projects. Current account surpluses are expected during 2013-14, reflecting a recovery in the diamond sector and electricity exports to South Africa. The external debt-to-export ratio is projected to rise significantly beginning in 2009 and to reach a peak of 121.1 percent in 2011 before gradually falling to 86.5 percent by 2014 .

3. The bounds tests suggest that Botswana's external debt position would remain sustainable even if there are shocks. Botswana's external debt-to-GDP ratio is robust to growth and interest rate shocks, but appears more sensitive to a current account shock and an exchange rate shock (a 30 percent depreciation), and to a combination of growth, interest rate, and current account shocks. 
Table 1. Country: External Debt Sustainability Framework, 2004-2014

(In percent of GDP, unless otherwise indicated)

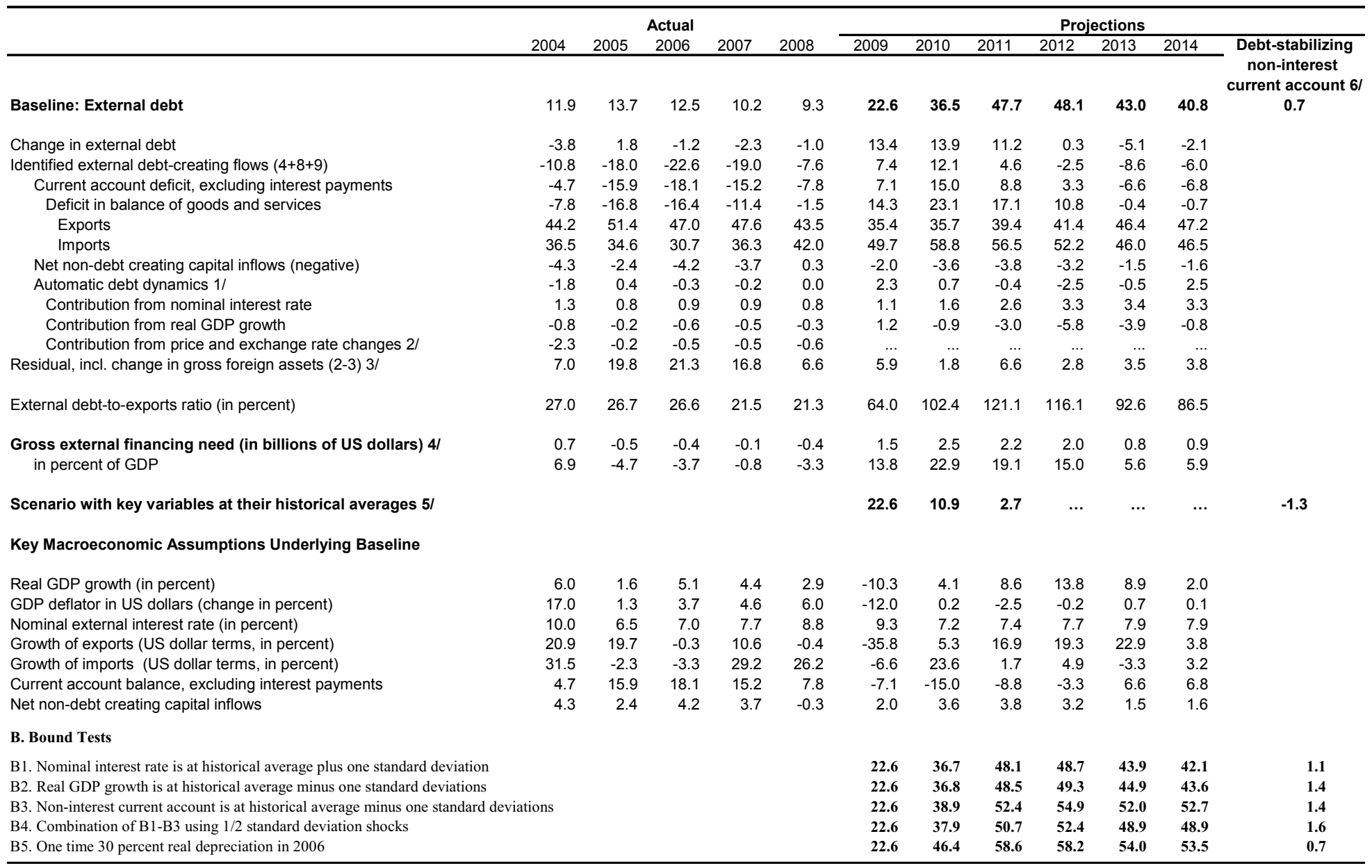

$1 /$ Derived as $[r-g-\rho(1+g)+\varepsilon \alpha(1+r)] /(1+g+\rho+g \rho)$ times previous period debt stock, with $r=$ nominal effective interest rate on external debt; $\rho=$ change in domestic GDP deflator in US dollar terms, $g=$ real GDP growt $\varepsilon=$ nominal appreciation (increase in dollar value of domestic currency), and $\alpha=$ share of domestic-currency denominated debt in total external debt.

$2 /$ The contribution from price and exchange rate changes is defined as $[-\rho(1+g)+\varepsilon \alpha(1+r)](1+g+\rho+g \rho)$ times previous period debt stock. $\rho$ increases with an appreciating domestic currency $(\varepsilon>0)$ and rising inflation $(k$ $3 /$ For projection, line includes the impact of price and exchange rate changes.

4/ Defined as current account deficit, plus amortization on medium- and long-term debt, plus short-term debt at end of previous period.

5/ The key variables include real GDP growth; nominal interest rate; dollar deflator growth; and both non-interest current account and non-debt inflows in percent of GDP.

6/ Long-run, constant balance that stabilizes the debt ratio assuming that key variables (real GDP growth, nominal interest rate, dollar deflator growth, and non-debt inflows in percent of GDP) remain at their levels of the last projection year. 
Figure 1. Country: External Debt Sustainability: Bound Tests 1/ (External debt in percent of GDP)
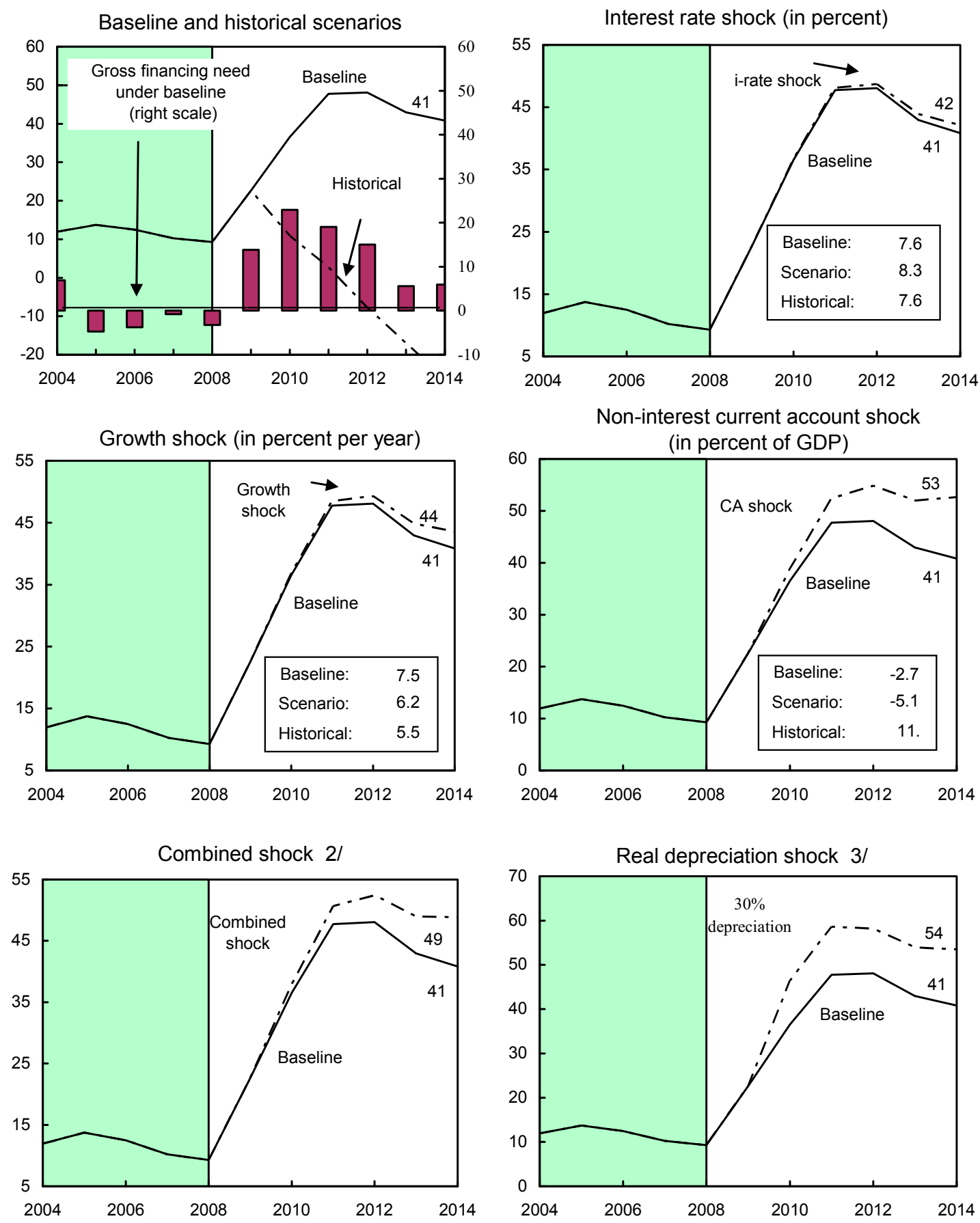

Sources: International Monetary Fund, Country desk data, and staff estimates.

1/ Shaded areas represent actual data. Individual shocks are permanent one-half standard deviation shocks. Figures in the boxes represent average projections for the respective variables in the baseline and scenario being presented. Ten-year historical average for the variable is also shown.

2/ Permanent 1/4 standard deviation shocks applied to real interest rate, growth rate, and current account balance.

3/ One-time real depreciation of 30 percent occurs in 2009. 


\section{IMF Executive Board Concludes 2009 Article IV Consultation with Botswana}

On July 20, 2009, the Executive Board of the International Monetary Fund (IMF) concluded the Article IV consultation with Botswana.

\section{Background}

Sound macroeconomic management, supported by strong institutions and good governance, has underpinned strong economic growth in Botswana for the past four decades. Annual real gross domestic product (GDP) growth averaged nearly 10 percent per year from 1960 through 2008 , supported by increased mining production and more recently by stronger growth in the nonmining economy as the mining sector has matured. As a result, real per capita income increased from US\$250 in 1960 to US $\$ 4,800$ in 2008 (in constant 2000 US\$).

Prudent management of diamond revenues, together with high minerals prices, resulted in large fiscal and external surpluses in recent years. International reserves amounted to 21 months of imports of goods and services by end-2008, boosted by the accumulation of sizable fiscal savings.

Despite this impressive progress, considerable social challenges remain. HIVIAIDS is a serious problem, while poverty, unemployment, and income inequality are all high for a middle-income country. In addition, the economy continues to rely heavily on diamond mining, which is expected to decline after 2020.

After several years of robust growth, real GDP growth slowed to 2.9 percent in 2008 due to a decline in mining output. The decline in diamond exports, together with a large increase in public infrastructure-related imports, reduced the current account surplus to 7 percent of GDP in 2008 from an average surplus of 15.6 percent of GDP during 2005-2007. The nonmining primary deficit (NMPD) increased to 28.6 percent of non-mining GDP in 2008/09 from 16.8 percent in 2007/08, reflecting a large increase in public investment and further growth in the wage bill. 
The real effective exchange rate has stabilized since the shift to the crawling peg regime in May 2005, although Botswana's higher inflation vis-à-vis its trading partners resulted in a modest appreciation in 2008 and early 2009. The 12-month inflation rate fell to 8.4 percent in May 2009 from 15 percent in mid-2008, mostly reflecting reduced pressure on fuel and food prices. With inflationary pressures easing, the Bank of Botswana has reduced its main interest rate by 400 basis points since December 2008 with a view to stimulating economic activity.

The financial sector has weathered the global economic downturn thus far, although nonperforming loans have edged up in late 2008 and early 2009 . There has been notable progress on supervision of the nonbanking financial sector, including the establishment of a Non-Bank Financial Institutions Regulatory Authority (NBFIRA). There are still several recommendations from the 2007 Financial Sector Assessment Program (FSAP) mission that remain on the agenda.

The current global economic crisis has reduced demand for diamonds and contributed to a significant deterioration in the economic outlook. The economy is now projected to contract sharply in 2009, and large fiscal and external deficits are anticipated. Inflation has slowed considerably and is projected to fall to 7 percent by the end of 2009. Looking ahead, Botswana's near-term macroeconomic outlook is uncertain, with significant downside risks in the event of a slower than expected recovery in diamond demand. Two large electricity generation projects should boost output as they come online in 2012-13.

\section{Executive Board Assessment}

Executive Directors agreed with the thrust of the staff appraisal. They commended the authorities for their prudent macroeconomic management, underpinned by strong institutions and good governance, which has contributed to rapid growth, large fiscal and external surpluses, and a significant build up of international reserves. Directors observed that the current global economic crisis has contributed to a significant deterioration in the economic outlook for Botswana with near-term downside risks. With a recovery in diamond exports expected to be sluggish, large fiscal and external deficits are likely to persist for the next several years. A slower-than-expected recovery in diamond demand would add to pressure on the external and fiscal positions. Directors noted that Botswana also faces the challenge of diversifying from diamond production and tackling high unemployment, HIVIAIDS prevalence, and income inequality.

Directors agreed that the recent marked increase in expenditures raises concerns about spending quality and fiscal sustainability. As a large part of this increase reflected outlays for infrastructure investment, a return to a more sustainable level of spending could take place as these projects are completed. They called for the authorities to scale back the public sector wage bill to create fiscal space for the recurrent costs associated with the completed projects, as well as for social spending. Directors noted that on current fiscal policies, the fiscal adjustment to achieve fiscal sustainability in the medium term would be larger than currently envisaged. 
Directors encouraged the authorities to consider a fiscal rule that is based on the nonmining primary deficit as a share of nonmining GDP rather than the present rule, which limits overall expenditure relative to GDP. They noted that such a rule would provide a clearer picture of the underlying fiscal stance and be a better indicator of longer-term fiscal sustainability. Directors also encouraged the authorities to develop a Medium-Term Expenditure Framework in order to improve public expenditure management and increase spending efficiency.

Directors agreed that the weak outlook for growth and easing of inflationary pressures had provided room for easing monetary policy in 2009. Directors generally welcomed the recent easing of monetary policy. They encouraged the authorities to continue to weigh carefully the balance of inflation risk in their monetary policy decision.

Directors noted that the crawling peg has resulted in greater stability of the real effective exchange rate. They also noted staff's assessment that the real effective exchange rate is modestly overvalued. The limited scope for real exchange rate adjustment underscores the need for fiscal consolidation and structural reform to ensure medium-term external stability and competitiveness. Over the medium term, a few Directors encouraged greater exchange rate flexibility if the inflation objective were to become the primary monetary policy anchor.

Directors observed that the global financial crisis has not had a significant adverse impact on the banking sector to date. Nevertheless, they urged the authorities to remain vigilant, as the marked economic contraction expected in 2009 could increase stress on bank balance sheets. Directors welcomed the establishment of the Non-Bank Financial Institutions Regulatory Authority, but noted that further steps are needed to enhance its capacity, including through technical assistance, given the sizable reform agenda ahead. They encouraged the authorities to address the remaining issues from the FSAP recommendations.

Directors noted that Botswana needs to accelerate economic diversification in order to reduce vulnerability to shocks in the diamond trade. They urged the authorities to ensure that the increased spending on infrastructure, education, and health results in outcomes that are commensurate with these additional expenditures. They also called on the authorities to accelerate key structural reforms, which would reduce the cost of doing business and enhance productivity.

Public Information Notices (PINs) form part of the IMF's efforts to promote transparency of the IMF's views and analysis of economic developments and policies. With the consent of the country (or countries) concerned, PINs are issued after Executive Board discussions of Article IV consultations with member countries, of its surveillance of developments at the regional level, of post-program monitoring, and of ex post assessments of member countries with longer-term program engagements. PINs are also issued after Executive Board discussions of general policy matters, unless otherwise decided by the Executive Board in a particular case. 
Botswana: Selected Economic Indicators

\begin{tabular}{|c|c|c|c|c|c|}
\hline & 2005 & 2006 & 2007 & 2008 & $\begin{array}{l}2009 \\
\text { Proj } \\
\end{array}$ \\
\hline & \multicolumn{5}{|c|}{ (Annual percentage change, unless otherwise indicated) } \\
\hline \multicolumn{6}{|l|}{ National income and prices } \\
\hline Real GDP 1/ & 1.6 & 5.1 & 4.4 & 2.9 & -10.3 \\
\hline Mineral & 1.9 & 7.9 & -2.0 & -3.7 & -36.7 \\
\hline Non-mineral & 1.4 & 3.2 & 9.0 & 7.2 & 4.9 \\
\hline Consumer prices (average) & 8.6 & 11.6 & 7.1 & 12.6 & 8.7 \\
\hline Consumer prices (end of period) & 11.3 & 8.5 & 8.1 & 13.7 & 7.0 \\
\hline Nominal GDP (billions of pula) 1/ & 52.4 & 65.7 & 75.7 & 91.2 & 80.1 \\
\hline Diamond production (millions of carats) & 31.8 & 34.3 & 33.6 & 32.6 & 20.0 \\
\hline \multirow[t]{2}{*}{ Money and quasi money (M2) } & 10.6 & 67.4 & 31.2 & 21.1 & 14.9 \\
\hline & \multicolumn{5}{|c|}{ (Percent of GDP, unless otherwise indicated) } \\
\hline \multicolumn{6}{|l|}{ Central government finance $2 /$} \\
\hline Total revenue and grants & 39.9 & 40.2 & 36.0 & 34.2 & 32.2 \\
\hline Total expenditure and net lending & 31.6 & 28.9 & 31.2 & 39.5 & 43.2 \\
\hline Overall balance (deficit -) & 8.3 & 11.2 & 4.8 & -5.2 & -11.1 \\
\hline Non-mineral primary balance (percent of non-mineral GDP) $3 /$ & -20.5 & -14.8 & -16.8 & -28.6 & -28.3 \\
\hline \multicolumn{6}{|l|}{ External sector } \\
\hline Current account balance & 15.2 & 17.2 & 14.3 & 7.0 & -8.2 \\
\hline Balance of payments & 13.4 & 15.6 & 14.1 & 8.2 & 0.9 \\
\hline External public debt $4 /$ & 4.2 & 3.3 & 2.5 & 2.3 & 11.7 \\
\hline \multirow[t]{2}{*}{ External public debt in percent of total exports } & 8.1 & 6.9 & 5.3 & 5.3 & 33.2 \\
\hline & \multicolumn{5}{|c|}{ (In millions of US dollars, unless otherwise indicated) } \\
\hline Gross official reserves (end of period) & 6,278 & 7,954 & 9,743 & 9,125 & 9,220 \\
\hline In months of imports of goods and services $5 /$ & 21.7 & 21.3 & 20.7 & 20.8 & 17.0 \\
\hline In percent of GDP & 60.6 & 70.4 & 79.0 & 67.8 & 86.8 \\
\hline Pula Fund & 4,511 & 6,110 & 6,614 & 6,866 & .. \\
\hline In months of imports of goods and services 5 / & 15.6 & 16.4 & 14.1 & 15.6 & . \\
\hline Liquidity portfolio/ other reserves & 1,767 & 1,844 & 3,130 & 2,259 & ... \\
\hline In months of imports of goods and services $5 /$ & 6.1 & 4.9 & 6.6 & 5.1 & ... \\
\hline Terms of trade (Annual percentage change) & 14.5 & -1.8 & 1.0 & 7.9 & -16.5 \\
\hline
\end{tabular}

Sources: Botswana authorities; and IMF staff estimates and projections.

1/ Calendar year.

2/ Year beginning April 1.

$3 /$ The nonmineral primary balance is computed as the difference between non-mineral revenue and expenditure (excluding interest receipts and interest payments), divided by non-mineral GDP.

4/ Medium- and long-term public and publicly guaranteed debt outstanding.

5/ Based on imports of goods and services for the following year. 


\section{Statement by Mr. Itam on Botswana \\ July 20, 2009}

\section{Introduction}

On behalf of my Botswana authorities, I would like to thank staff for the candid and productive discussions during the Article IV mission. I also thank the Executive Board and Management for their continued support. The authorities value the advice proffered by the Fund and are in general agreement with the thrust of the staff reports.

Following decades of high and sustained growth, which was supported by prudent economic management, the Botswana economy has been hard hit by the effects of the global recession, which has negatively affected growth through reduced diamond output. The slowdown in the diamond sector also affected the fiscal and external sector performance through lower revenues and exports, respectively. In the short term, the authorities have implemented some infrastructure projects to stimulate domestic demand and alleviate the impact of the recession on growth, while in the medium to long run they plan to facilitate diversification of the economy in order to reduce vulnerability to external shocks.

The authorities remain committed to the implementation of prudent policies, which have supported the country's strong economic performance over the years, in order to preserve macroeconomic stability and promote sustainable economic growth.

\section{Recent economic developments and outlook}

The effects of the global recession on the Botswana economic performance and outlook have been transmitted primarily through the diamond sector, which continues to be the mainstay of the economy. Economic growth slowed down from an average of 4 percent over the last five years to about 3 percent in 2008, with the value added in diamond mining falling significantly in the last quarter.

A sharp economic contraction, coupled with the widening of the fiscal and external deficits, is expected in 2009 as activities were suspended during the first four months of 2009 because of weak demand. Total production for the year is projected at only half of that realized in 2008. However, the economic slowdown is expected to be dampened by construction activities emanating from a number of ongoing government infrastructure projects.

Due to the country's openness and susceptibility to shocks, inflation has, for the most part, remained above the Central Bank target range of 3-6 percent. In 2008, inflation was driven largely by high fuel and food prices. Since then, inflation has been on a downward trend and is expected to continue to move towards the upper end of the target in line with easing of food and fuel prices. 
Fiscal performance has deteriorated, with the overall balance shifting into deficit in FY2008/09 as a result of a fall in revenues due to lower global demand for diamonds coupled with high public spending, including major infrastructure projects. The overall fiscal deficit is expected to widen in FY 2009/10, as government revenue continues to be adversely effected by the global crisis and as SACU revenue possibly declines on account of lower regional imports. The overall budget deficit of some 11 percent of GDP is expected to be financed largely by an AfDB budget support loan.

The balance of payments position is expected to deteriorate in 2009 and 2010, with the current account balance shifting to deficit as a result of lower diamond exports and increased imports to support the construction of power projects. However, the situation is expected to improve in the medium term as the demand for diamonds recovers and capital imports level off. Consequently, the level of international reserves is expected to remain comfortable, at 16 months of import cover or higher during the short to medium term.

\section{Macroeconomic policies}

\section{Fiscal policy}

The authorities are committed to sound fiscal policies, which have led to fiscal surpluses and facilitated significant accumulation of reserves. The authorities are cognizant of the need to contain spending in order to ensure fiscal sustainability in light of the recent setbacks. However, they are of the view that increased spending at this time will be beneficial in mitigating the effects of the contraction in the diamond sector. The increase in infrastructure spending is considered to be temporary and is expected to fall as the ongoing projects are completed. The authorities are focusing on improving the efficiency of public expenditure. In this regard they have scaled down current expenditures from the original 2009/10 budget. They are also examining options for more cost effective public service delivery, in order to help contain further recurrent spending. The authorities are also open to the idea of revising their fiscal rule to incorporate a link to non-mining GDP. Such a revision will be considered as part of the National Development Plan 10 (NDP 10). On the revenue front, the authorities plan to concentrate on improving tax administration in order to strengthen nonmining tax revenues over the medium term.

\section{Monetary policy and financial sector issues}

Monetary policy will continue to aim at containing inflation within the medium-term target range of 3-6 percent. However, the Bank of Botswana is also mindful of the need to support domestic demand in response to the global recession. In this regard, the easing of inflation, although still above the target range, has allowed some loosening of monetary policy. The authorities have continued to strengthen their inflation forecasting model, but do not plan to move to a full fledged inflation targeting framework immediately. 
The effect of the global financial crisis on the financial sector has thus far been minimal. Commercial banks continue to be well capitalized, liquid and profitable. Non-performing loans are low but could rise as economic conditions deteriorate. The authorities are closely monitoring the situation and have developed supervision guidelines for distressed banks. The authorities are making some progress in implementing the FSAP mission recommendations, notably on improving supervision of nonbank financial sector. The Nonbank Financial Institutions Regulatory Authority (NBFIRA) has been established and is expected to assume supervisory responsibilities for the nonbank sector by the end of the year. The authorities are committed to the implementation of the remaining FSAP recommendations.

\section{Growth policies}

Diversification of the economy, with the aim of boosting growth and reducing vulnerability to external shocks, is high on the authorities' development agenda. The need for diversification has been heightened by the recent abrupt economic contraction which emanated primarily from the effect of the global slowdown on the diamond mining sector. In the short term, the authorities have increased spending on infrastructure to boost domestic demand and dampen the effects of the global economic downturn.

For the medium term, the authorities have developed the new development plan (NDP 10) whose implementation is expected to begin in April next year. The main emphasis of the plan is economic diversification, job creation and poverty alleviation. The diversification strategy will concentrate on infrastructure investment and development of the agriculture, transport, tourism, education and health sectors as well as the downstream activities in the diamond sector, and improvement of the energy sector. The authorities will also enhance the investment climate by addressing the structural aspects of competitiveness.

\section{Conclusion}

In conclusion, I wish to reaffirm the authorities' commitment to the prudent macroeconomic management which has facilitated macroeconomic stability and impressive growth in the past. Diversification of the economy remains high on the agenda. The authorities appreciate the support of the Fund and the international community in their development endeavors. 